\title{
Comparability of Company Accounts Using IFRS and US GAAP: Empirical Evidence of European and US Financial Statements
}

\author{
Federica Doni ${ }^{1}$, Ross H. Taplin ${ }^{2}$ \& Roberto Verona ${ }^{3}$ \\ ${ }^{1}$ Department of Business Administration, Finance, Management and Law, University of Milan-Bicocca, Italy \\ ${ }^{2}$ Department of Auditing, Assurance \& Accounting Technologies, Curtin University of Technology, Australia \\ ${ }^{3}$ Department of Economics and Management, University of Pisa, Italy \\ Correspondence: Federica Doni, Department of Business Administration, Finance, Management and Law, \\ University of Milan-Bicocca, Italy. Tel: 39-026-448-3182. E-mail: federica.doni@unimib.it
}

Received: August 15, 2016

doi:10.5539/ijbm.v11n12p54
Accepted: September 18, 2016 Online Published: November 20, 2016

URL: http://dx.doi.org/10.5539/ijbm.v11n12p54

\begin{abstract}
Purpose-The main objective of this study is to provide a judgment on the comparability of financial statements prepared under IFRS and US-GAAP. We developed two research questions for evaluating comparability within Europe (IFRS) and within the US (US GAAP) and for testing whether comparability is higher or lower when the US companies are included with the European countries.

Design/Methodology/Approach-The $\mathrm{T}$ index framework was used to summarize the level of comparability for 13 accounting items using data from 250 companies.

Findings-Empirical results are mixed. Of 13 accounting items considered, international comparability is significantly lower for 7 items and significantly higher for 4 items when the US companies are included. Furthermore, comparability amongst companies using IFRS is not consistently higher or lower than comparability amongst companies using US GAAP.

Practical implications-Answers to the research questions may provide useful suggestions for IASB's current policy direction towards global accounting standards convergence, and in particular for the IASB-FASB convergence project. The results also have implications for companies or countries considering shifting to IFRS or US GAAP.

Research limitations/implications-Lack of comparability within countries, rather than between countries, suggests a need to focus on reducing options within standards rather than on differences between standards or countries.
\end{abstract}

Originality value-Our empirical results show that in most cases lack of comparability may be driven by options within a standard rather than by explicit differences between standards.

Keywords: IFRS, US GAAP, T index, comparability, option

JEL descriptors: M10, M16, M40, M41

\section{Introduction}

The recent process of accounting harmonisation made possible by the adoption in 2005 of IFRS represents the beginning of a practice tending to overcome the accounting differences not just at European level but more generally on a worldwide scale for the progressive adoption of a common global accounting language (Mc Gregor, 1999; Erikson, Esplin, \& Maines, 2009; Price Waterhouse Coopers (PWC), 2010; Wagenhofer, 2009; Upton, 2010). It emerges a super partes need for a project of convergence between the European discipline IAS/IFRS with the American accounting principles US GAAP, which justifies the progressive harmonisation of these two accounting systems (Tarca, 2005; Schipper, 2005; Callagan \& Treacy, 2007; Hail, Leuz, \& Wysocki, 2010a). This process of harmonisation would also represent a significant input for the globalisation of financial markets: accounting information could reach a great level of homogenisation to allow the comparison between financial, economic and capital data and the consequent improvement of economic and financial communication. The exigency of reaching a definition of a unified set of accounting principle will not just result in the effective solution of the 'Tower of Babel accounting' (Erikson et al., 2009) but also improve comparability of data, and 
financial and economic communication of stock markets (IASB Framework, p. 39).

The coexistence of two sets of accounting standards and the need highlighted by the two standard setters to promote the convergence process (Schipper, 2005) are the main motivations for this paper. The extent to which the comparability between companies of the major European countries is higher or lower than the comparability between US companies provides insights into whether IFRS or US GAAP produces higher comparability. Furthermore, the extent to which the addition of US companies to European companies reduces comparability adds insights into the consequences of having two standards. These issues are summarised with the following two research questions concerning the level of comparability in the financial statements of companies:

1) Is comparability higher or lower within Europe countries (IFRS) or within the US (US GAAP)?

2) Is international comparability higher or lower when the US companies are included with the European companies?

Unlike past literature that focusses on assumed relationships between overall financial outputs such as earnings and returns (De Franco, Kothari, \& Verdi, 2011) or stock price, stock return and cash flow (Barth, Landsman, Lang, \& Williams, 2012), this paper examines these questions for 13 individual accounting items, both for presentation of information and calculation of accounting numbers This more directly addresses the comparability of company accounts from the perspective of specific accounting standards and identifies where lack of comparability exists.

These questions are relevant at several levels, including academic and for professionals who operate in the accounting and financial sectors. An understanding of where differences occur in practice (rather than just regulation) is important to inform debate concerning appropriate standards and the extent to which national and international comparability is an issue, especially where options are permitted. Lack of comparability can justify the conclusion 'I do not suggest that the use of appropriate principles would lead inexorably to standards with no optional methods but that, on some topics, optional methods could be eliminated' (Nobes, 2004). Answers to these questions may provide useful suggestions for IASB's current policy direction towards global accounting standards convergence, and in particular for the IASB-FASB convergence project. The results also have implications for companies or countries considering shifting to IFRS or US GAAP.

The paper proceeds as follows: Section 2 focuses on developments in the process of convergence between IFRS and US GAAP, Section 3 summarises relevant literature on international accounting harmonization; Section 4 explains the methodology focusing on a selection of countries, firms and accounting issues and on the statistical analysis; Section 5 provides the results of the research; Section 6 draws a summary and conclusions.

\section{The Global Convergence between IFRS and US GAAP}

Accounting standards are the main drivers of financial reporting quality but they differ across countries (Ding, Hope, Jeanjean, \& Stolowy, 2007). The mandatory adoption of IAS/IFRS by the European Union (Note 1) has received significant consideration from investors, regulators and academics. The formal commitment by the US Financial Accounting Standard Board and the International Accounting Standard Board (IASB) to converge US GAAP with IAS/IFRS has enhanced the acceptance and the implementation of IFRS in the world and it represents a considerable effort to develop high quality, internationally comparable financial information.

The process of convergence started in October 2002 with a Memorandum of Understanding ('The Norwalk Agreement', 2002) that included the adoption of a common plan of development between the two Boards in order to overcome the differences existing between IFRS and US GAAP and to enhance the coordination of the two bodies in charge of interpreting the protocols, namely the IFRIC for the IASB and the EITF of AICPA for the US GAAP. Due to unsatisfactory operational results obtained, in 2006 a second Memorandum was adopted (A Roadmap for Convergence between IFRSs and US GAAP-2006-2008 Memorandum of Understanding between the FASB and the IASB, 27 February 2006). In light of the second report new lines of actions emerged to remove in the short term the differences between the two standards on specific issues and to deal with larger scale issues, which demand the adoption of a proper accounting principle common to the two boards. This process of harmonisation between IFRS and US GAAP was significantly accelerated by the decision issued in 2007 by the SEC to eliminate the reconciliation requirement for foreign registrants that use IFRS as issued by the IASB (Acceptance from foreign private issuers of financial statements prepared in accordance with International Financial Reporting Standards without reconciliation to GAAP, December, 2007).

In 2008, the two standard setters identified a number of priorities in order to complete the more relevant joint projects by 2011, 'emphasising the goal of a joint project to produce common, principle-based standards' (IASB). As a result of the request adopted by the G20 to complete the convergence process by June 2011, in November 
2009, IASB and FASB published a progress report indicating the intention of intensifying the program by increasing the frequency of meetings and of reports, issued every four months (Quarterly Progress Report).

In November 2008, the SEC proposed a 'Roadmap for Potential Use of Financial Statements Prepared in Accordance with International Financial Reporting Standards (IFRS) by US Issuers'. The SEC roadmap detailed a process and a set of milestones by which certain larger public companies (those with a public float of at least $\$ 700$ million) in the United States would transition from financial reporting based on US Generally Accepted Accounting Principles (GAAP) to that based on IFRS (Liu \& Hiltebeitel, 2010). The SEC received over 200 comment letters on the Roadmap. In addition to the evident effects in terms of accounting harmonisation, the SEC is likely motivated to maintain the strong appeal of the New York Stock Exchange for foreign firms, which are already bearing high costs of implementation of IFRS.

The process of harmonisation between IFRS and US GAAP can therefore be seen to be slow, problematic, and a process that is still evolving. A recent survey found nearly $50 \%$ of U.S.-based multinational companies are either using IFRS somewhere in the world, have completed an initial impact assessment, or are planning to do an assessment (PWC, 2010). At the annual AICPA National Conference on SEC and PCAOB Developments (December 2013) IASB Chair Hans Hoogervorst confirmed the IASB's mission of global accounting standards and the engagement with the increase of transparency, creating the Accounting Standards Advisory Forum (ASAF). The IFRS footprint is already large and it is expected to continue growing as economic globalization continues to increase. The mission of ASAF is to continue deepening its cooperation with national standard setters, such as FASB, and to ensure that IFRS meets the needs of all capital markets, including the United States (Murphy, 2014).

It is therefore important to assess the characteristics of the two accounting systems in light of the difficulties about the potential replacement of the US GAAP with IFRS. The analysis of the differences between the American, rule-based, and the European, principles-based, systems (Schipper, 2003; Nobes, 2004; Staunton, 2008; Sunder, 2009) has been the object of comparative research on different accounting systems (Saudagaran \& Biddle, 1995; Durand \& Tarca, 2005; Tarca, 2005) and on different approaches to corporate reporting regulation (Leuz, 2010).

The development of studies on IFRS are anticipating the global adoption of the IFRS despite the role played by US GAAP (Erchinger \& Melcher, 2007). In this context, a range of different prospects have emerged in regard to the use of US GAAP (Bradshaw et al., 2010; Ohlson et al., 2010), where the two extreme situations are represented by the maintenance of US GAAP with the acceptance of IFRS only for foreign companies, and the creation of I-GAAP, international US GAAP as 'a competitive set of international standards that could serve as an alternative to IFRS' (Hail et al., 2010a, 2010b). The debate on IFRS adoption in the US is still relevant and the findings of a survey conducted on the investor perceptions highlighted the importance of convergence to investors (Joos \& Leung, 2013).

\section{Literature Review}

The objectives of the International Accounting Standard Committee Foundation (IASCF) include the development of 'a single set of high quality, understandable and enforceable global accounting standards' and 'to promote the use and rigorous application of them' (International Accounting Standards Committee Foundation [IASCF], 2005, pr. 2). The willingness to create a set of global accounting standards (Wyatt, 1989) has strongly increased as a result of the IFRS - US GAAP convergence program, outlined jointly by the European and US standard setters. Hence, two key moments in international accounting harmonization can be identified: year 2002, when the Memorandum of Understanding between FASB and IASB was signed and the year 2005, where all companies domiciled in the European Union with shares listed on securities exchanges are required to prepare their consolidated accounts in accordance with IFRS.

From the '90s until the adoption of IFRS in 2005, comparative studies have focused on two different issues:

1) the study of the relationship between differences in accounting practices and share-price returns in international capital markets (Meek, 1991; Amir, Harris, \& Venuti, 1993; Pope \& Rees, 1992; Bandyopadhyay, Hanna, \& Richardson, 1994; Harris, Lang, \& Moller, 1994; Barth \& Clinch 1996; Rees \& Elgers, 1997; Harris \& Mueller, 1999; Adam, Weetman, \& Gray 1993; Alford, Jones, Leftwich, \& Zmijewski, 1993; Hellman, 1993; Rahman, Perera, \& Tower, 1994; Saudagaran \& Meek 1997; Weetman, Jones, Adams, \& Gray, 1998, Aboody Barth, \& Kasnik, 1999; Pownall \& Schipper, 1999; Guenther \& Young, 2000; Hung, 2000; Schipper, 2000; Asbaugh \& Pincus, 2001; Asbaugh \& Olsson, 2002; Dumontier \& Raffournier, 2002; Bhattacharya, Daouk, \& Welker, 2003, Leuz, 2003; Bradshaw, Bushee, \& Miller, 2004) and 
2) IFRS/US GAAP comparison (Bhoocha \& Stansell, 1990; Meek \& Saudagaran, 1990; Nobes, 1990; Biddle \& Saudgaran, 1991; Choi \& Levich, 1991; Cooke, 1993; Grove \& Bazley, 1993; Frost \& Pownell, 1994; Yang \& Lee, 1994; Boross, Clarkson, Fraser, \&Weetman, 1995; Roberts, Salter, \& Kantor, 1995; Schweikart, Gray, \& Salter, 1996; Zambon, 1996; Adhikari \& Emeyonu, 1997, Barniv \& Fetyko, 1997; Sutton, 1997; Nobes, 1998; Street \& Shaughnessy, 1998; Street \& Gray, 1999; Dye \& Sunder, 2001; Ding, Stolowy, \& Tenenhaus, 2003; Glaum \& Street, 2003; Tarca, 2004). To be noted is the study undertaken by Nobes, which found that the adoption of IAS had little impact on the financial reporting practices of American listed companies listed on European markets. A significant increase in convergence between IFRS and US GAAP was also revealed (Baker $\&$ Barbu, 2007). These researches were mainly of an empirical type.

The interest in comparing US GAAP and IFRS also generated another area focusing on the analysis of the reconciliation reports drawn up by EU companies listed on the US market (Meek, Roberts, \& Gray, 1995; Harris \& Muller 1999; Brennan \& Connell, 2000; Haverty, 2006; Zambon \& Crosara, 2007; Henry, Lin, \& Yang, 2009).

Van der Tas (1988) introduced indices to measure the extent of comparability (harmony) in the financial statements of companies and since then there has been significant improvements in methods, including criticism of existing indices and development of new indices (Cooke, 1989; Tay \& Parker, 1990; Herrman \& Thomas 1995; Archer, Delvaille, \& McLeay, 1995; Lainez et al. 1996, Archer, Delvaille, \& McLeay, 1996; Krisement, 1997; McLeay, et al. 1999, Canibano \& Mora 2000; Aisbitt, 2001). This study uses the flexible framework of indices called the T index (Taplin, 2004; Astami et al., 2006) which has been extended to incorporate statistical inference techniques to allow testing of hypotheses (Taplin, 2010) and sophisticated practices to deal with previous criticisms of indices (Taplin, 2011).

Another research stream concerns the impact of the implementation of IFRS in different European countries and in the rest of the world, and thus multiple comparisons were carried out by evaluating financial statements pre-transition and post-transition to IFRS (Raty, 1992; Glaum, 2000; Street \& Bryant, 2000; Larson \& Street, 2004). These researches were conducted in Asian countries, such as China and Japan (Cooke, 1991; Kikuya, 2001; Chen, Sun, \& Wang, 2002; Taplin, Tower, \& Hancock, 2002; Abd-Elsalam \& Weetman, 2003; Xiao, Weetman, \& Sun, 2004; Al-Shammari, Brown, \& Tarca, 2008; Peng, Tondkar, Smith, \& Harless, 2008). The methodology used is both empirical and normative/descriptive.

Following the implementation of IFRS, the issue of harmonization has moved in two different directions: 1) to assess the differences between IFRS and local GAAP, conducting empirical research to demonstrate the benefits arising from the use of IFRS in terms of improved quality and transparency of information in the financial statements (Prather-Kinsey \& Shelton 2005; Soderstrom \& Sun 2007; Barth, Landsman, \& Lang, 2008; Beattie, Fearnely, \& Hines, 2008; Daske, Hail, Leuz, \& Verdi, 2008; Rahaman, Yammeesri, \& Perera, 2010; Phillips, Drake, \& Luehlfing, 2010; Armstrong, Guay, \& Weber, 2010; De Franco et al., 2011), 2) to investigate the possible continued existence of differences in accounting policies or choices despite respecting the same accounting rules (Nobes, 2006; Kvaal \& Nobes, 2010; Nobes, 2011; Jones \& Finley, 2011; Kvaal \& Nobes, 2012; Nobes \& Stadler, 2013; Cairns, Massoudi, Taplin, \& Tarca, 2011).

This study is positioned within this research stream, with the aim of empirically evaluating the level of comparability in the financial statements of companies. This study will extend past literature by considering comparability after the adoption of IFRS and considering the impact of including, or excluding, the US from European companies. This provides a comparison of IFRS and US GAAP not only relating to options allowed under each regime but importantly in terms of actual reporting practices of companies. Thus this paper combines the two recent research directions by examining comparability in specific accounting policy choices across IFRS and US GAAP.

\section{Methodology}

The US had the highest Gross Domestic Product (GDP) in the world in 2009, so for comparison this paper also includes the countries Germany, France, the United Kingdom and Italy since these European countries also have high GDP. Excluding smaller European countries provides a fairer and more useful comparison of US GAAP and IFRS as including many smaller European countries are of less interest to international investors. Larger companies have greater influence on equity markets (Cairns et al., 2011), greater attention to compliance with IFRS and are of more importance to the global investor community (Chaplinski \& Ramanchad, 2000; Wu \& Kwok, 2002). Thus the 50 largest companies (by market capitalization) were selected in each country, after excluding companies in the financial sector. Thus our conclusions relate to the largest companies in the largest countries rather than a more overall perspective of all companies. This represents the dominate companies more likely to be trendsetters during international convergence and of most interest to international investors. In 
addition, companies were grouped into five industries: basic materials, oil \& gas; consumer goods; consumer services, health care; industrials; technology, telecommunication, utilities (Table 1).

Table 1. Distribution of sampled companies across industry and country

\begin{tabular}{lllllll}
\hline & France & Germany & Italy & UK & US & Total \\
\hline Basic materials, oil \& gas & 4 & 10 & 5 & 16 & 6 & $\mathbf{4 1}$ \\
Consumer goods & 9 & 12 & 12 & 7 & 8 & $\mathbf{4 8}$ \\
Consumer services, health care & 11 & 10 & 11 & 15 & 17 & $\mathbf{6 4}$ \\
Industrials & 15 & 9 & 12 & 5 & 7 & $\mathbf{4 8}$ \\
Technology, telecommunications and utilities & 11 & 9 & 10 & 7 & 12 & $\mathbf{4 9}$ \\
Total & $\mathbf{5 0}$ & $\mathbf{5 0}$ & $\mathbf{5 0}$ & $\mathbf{5 0}$ & $\mathbf{5 0}$ & $\mathbf{2 5 0}$ \\
\hline
\end{tabular}

Annual reports (consolidated financial statements) for year end 2009 were collected directly from company websites. The financial crisis occurred in late 2008, and hence the first effects on the financial and economic situation of companies can be found during this financial year. The date of the financial year-end varies from company to company, although most end on 31/12/2009, both in Europe and in the US.

In our analysis we selected 13 issues for examination (Table 2a). Of these, six concern the presentation of the financial statement and seven concern the recognition and measurement criteria of specific accounting items. In particular, in terms of the issues related to presentation, several can be described as 'cosmetic' (Note 2), such as issue 5, while others are related to the way of determining income or cash flow, such as issue 6 . These 13 issues were selected based on Kvaal and Nobes (2010) and either IFRS or US GAAP allowing for options (Table 2b).

Table 2a. Issues selected for examination

\begin{tabular}{ll}
\hline $\mathrm{N}$. & Issues \\
\hline 1 & Income statement \\
2 & Income statement \\
3 & Extraordinary items \\
4 & Terminology adopted \\
5 & Financial statement presentation \\
6 & Statement of Cash Flows \\
7 & PPE Evaluation \\
8 & Identifiable intangible assets \\
9 & Impairment test \\
10 & Inventory (valuation) \\
11 & Investment property \\
12 & Available for sales financial assets \\
13 & Provision for pension: actuarial gain and losses \\
\hline
\end{tabular}

Table 2b. Policy issues and differences between IFRS and US GAAP

\begin{tabular}{|c|c|c|c|}
\hline Issue & Topic & IFRS & US GAAP \\
\hline 1 & $\begin{array}{l}\text { Income Statement: free or fixed format } \\
\text { in accordance with specific rules }\end{array}$ & $\begin{array}{l}\text { There is no standard format. } \\
\text { A line item indicating EBITDA or operating } \\
\text { profit. }\end{array}$ & $\begin{array}{l}\text { The multiple-step or single-step format or } \\
\text { a format with multiple sub-group profit } \\
\text { lines must be used. }\end{array}$ \\
\hline 2 & $\begin{array}{l}\text { Classification of expenses: by nature or } \\
\text { function }\end{array}$ & Both criteria are permitted & $\begin{array}{l}\text { Mandatory presentation of costs by } \\
\text { function }\end{array}$ \\
\hline 3 & Non-recurring/ extraordinary items & $\begin{array}{l}\text { The presentation of non-recurring income and } \\
\text { expense is prohibited as a separate item. }\end{array}$ & $\begin{array}{l}\text { The presentation of extraordinary items is } \\
\text { permitted in limited circumstances. }\end{array}$ \\
\hline 4 & $\begin{array}{l}\text { Use of different terminology (strict or } \\
\text { optional) for the Income Statement } \\
\text { format }\end{array}$ & Income statement & $\begin{array}{l}\text { Income statement } \\
\text { Operations statement Earnings statements }\end{array}$ \\
\hline
\end{tabular}




\begin{tabular}{|c|c|c|c|}
\hline & & Operating cycle & \\
\hline 5 & $\begin{array}{l}\text { Presentation of assets and liabilities in } \\
\text { the Balance Sheet }\end{array}$ & $\begin{array}{l}\text { Financial method (offered for financial } \\
\text { companies only) } \\
\text { Mixed method (in such cases, generally, } \\
\text { increasing liquidity) }\end{array}$ & $\begin{array}{l}\text { Choice between reclassified or } \\
\text { non-reclassified Balance Sheet. } \\
\text { Increasing/decreasing liquidity (most } \\
\text { frequent practice) }\end{array}$ \\
\hline 6 & $\begin{array}{l}\text { Basis of preparation for the Statement } \\
\text { of Cash Flows }\end{array}$ & $\begin{array}{l}\text { Choice of direct or indirect method. Net profit } \\
\text { must be reconciled with net cash flows from } \\
\text { operating activities only when the indirect } \\
\text { method is applied. }\end{array}$ & $\begin{array}{l}\text { Choice of direct or indirect methods. The } \\
\text { difference compared to IFRS is that the } \\
\text { reconciliation of net income and net cash } \\
\text { flows from operating activities is required } \\
\text { in both cases. }\end{array}$ \\
\hline \multirow[t]{2}{*}{7} & $\begin{array}{l}\text { Historical cost or revalued cost (fair } \\
\text { value) }\end{array}$ & $\begin{array}{l}\text { Either option may be adopted. When revalued } \\
\text { cost is used, the entire asset category must be } \\
\text { revalued with sufficient regularity. }\end{array}$ & $\begin{array}{l}\text { Only historical cost is used, and no } \\
\text { revaluations are permitted, except for a } \\
\text { few exceptions. (There is no single } \\
\text { standard governing tangible assets, but } \\
\text { rather a series of different standards and } \\
\text { interpretations relating to the recognition } \\
\text { of tangible assets) NO CHOICE } \\
\text { Measurement at cost only. }\end{array}$ \\
\hline & Revaluation & Choice of the cost model or revaluation model & $\begin{array}{l}\text { Write-downs are permitted to reflect } \\
\text { impairment }\end{array}$ \\
\hline & Recognition & $\begin{array}{l}\text { Specific requirements must be met for } \\
\text { capitalization }\end{array}$ & Same as the IFRSs \\
\hline 8 & $\begin{array}{l}\text { Historical cost or revalued cost (fair } \\
\text { value) }\end{array}$ & $\begin{array}{l}\text { Either option may be adopted. Certain } \\
\text { categories of intangible assets that cannot be } \\
\text { revalued are listed below. In addition, there } \\
\text { must be an active market. The assets must } \\
\text { have the necessary characteristics in order to } \\
\text { determine that they have an active market. }\end{array}$ & $\begin{array}{l}\text { Only historical cost is used, and no } \\
\text { revaluations are permitted. } \\
\text { There is no specific regulation. } \\
\text { NO CHOICE }\end{array}$ \\
\hline 9 & Impairment test: the timing aspect & $\begin{array}{l}\text { At the end of each reporting period for } \\
\text { indefinite live assets and for long-lived assets } \\
\text { only upon occurrence of the events }\end{array}$ & Only upon occurrence of the events \\
\hline \multirow{2}{*}{10} & Measurement criterion & $\begin{array}{l}\text { They are stated at the lower of cost and net } \\
\text { realizable value. }\end{array}$ & Similar to IFRSs \\
\hline & Measurement & $\begin{array}{l}\text { The FIFO or the weighted average cost } \\
\text { method. LIFO is not permitted. }\end{array}$ & The LIFO method is permitted \\
\hline 11 & Measurement criterion & Measurement at amortized cost or fair value. & $\begin{array}{l}\text { The same treatment as for other types of } \\
\text { property (amortized cost). NO CHOICE }\end{array}$ \\
\hline & Measurement criterion & Measurement at fair value. & Same as IFRSs \\
\hline 12 & Positive or negative changes in value & $\begin{array}{l}\text { Unrealized gains/losses on financial } \\
\text { assets/liabilities recognized at fair value } \\
\text { through profit or loss (including securities held } \\
\text { for trading) are taken to profit or loss, while } \\
\text { those on investments are taken to equity. }\end{array}$ & $\begin{array}{l}\text { Changes in present value are taken to } \\
\text { stockholder's equity. If investment has an } \\
\text { other than temporary decline in fair value, } \\
\text { the investment loss is recognized in the } \\
\text { Income Statement. }\end{array}$ \\
\hline 13 & Inclusion in the financial statements & $\begin{array}{l}\text { Actuarial gains/losses can be taken to profit or } \\
\text { loss or recognized in equity. In this case, a } \\
\text { statement called the 'Statement of } \\
\text { Comprehensive Income' must be presented. } \\
\text { The corridor method ( } 10 \% \text { to the income } \\
\text { statement) is also provided for }\end{array}$ & $\begin{array}{l}\text { Recognition is in the income statement, } \\
\text { even if it can be taken to equity as long as } \\
\text { certain limits are not exceeded. Such gains } \\
\text { and losses are initially reflected in OCI, } \\
\text { but are subsequently amortized to profit or } \\
\text { loss. } \\
\text { The 'corridor' limits under US GAAPs } \\
\text { differ from those used under the IFRSs. }\end{array}$ \\
\hline
\end{tabular}

Furthermore, among the issues chosen, some can be ascribed to 'overt options', such as issues 2 and 5 . In some cases, these options are provided for under either IFRS or US GAAP but not both. For example, for the cost classification method, IFRS allows classification by both function and nature, while US GAAP requires classification of expenses by function. 
Authors with expertise in financial accounting obtained the accounting method used by each company by carefully scrutinizing their financial statements. In addition to the methods specified under IFRS and US GAAP, extra methods were created as they were encountered in financial statements. In particular, the following two options were added: 'Not applicable' identifies the absence in the corporate assets of the particular asset (e.g. inventory) under investigation; and 'Not disclosed' identifies the presence in corporate assets of the relevant asset under investigation, but the absence of any information in the financial statements on that specific issue.

$\mathrm{T}$ indices (Taplin, 2004) were used to summarize the level of comparability with standard errors calculated following Taplin (2010). The T index can take values between 0 and 1 and equals the probability that two randomly selected companies will have comparable accounts. The $\mathrm{T}$ index provides a flexible framework of indices by specifying alpha matrices summarizing the comparability of pairs of methods from 0 (completely not comparable) to 1 (completely comparable) and a beta matrix summarizing which companies are being compared. For example, the international focus can be used to compare all companies (option 2a), companies between countries (option $2 b$ ), or companies within the same country (option $2 c$ ).

Comparability between different accounting methods were summarized with alpha matrices containing 1 on the diagonals and 0 off the diagonals (indicating accounting methods are completely comparable with themselves and completely non-comparable with other methods) with the following exceptions: Income Statements neither by function nor by nature, Terminology adopted neither income statement nor operations statement, and Inventory valuation using neither FIFO nor average weighted cost, are non-comparable (alpha $=0$ ) with themselves; a mix of methods was not-comparable $($ alpha $=0)$ with itself for Inventory valuation however a mix of methods for any other policy choice were partially comparable $($ alpha $=0.5)$ with itself and all other methods. Furthermore, irrespective of the above, companies where the policy choice was not applicable were considered comparable $($ alpha $=1)$ with all other companies and companies not disclosing their method were considered not comparable (alpha $=0)$ with all other companies.

National $\mathrm{T}$ indices were calculated for each country as well as $\mathrm{T}$ indices with an overall, between country and within country international focus, both for the four European countries alone and for all five countries (the European countries and the USA). Companies were weighted equally in all cases. For each international focus, p-values were computed testing the null hypothesis $\mathrm{H} 0$ that $\mathrm{T}$ index values for Europe alone equal the index value for Europe with the USA. Testing this hypothesis using a within country focus answers the question of whether comparability within the US differs from comparability within European countries, and therefore provides insights concerning whether IFRS or US GAAP provides higher empirical comparability (research question 1). Testing this hypothesis regarding international comparability (overall or between country focus) provides insights concerning comparability between IFRS and US GAAP (research question 2).

All the above calculations were conducted both unconditionally and conditional on industry. Results conditional on industry are a modified version of the $\mathrm{T}$ index whereby only pairs of companies within the same industry are compared (Taplin, 2013). This removes any industry effects and uses a definition of harmony whereby companies operating under different circumstances should not be required to use comparable accounting methods to achieve perfect harmony (Jaafar \& McLeay, 2007).

\section{Results}

A summary of the data is provided in Table 3. The national comparability ( $T$ indices) within each country are presented in Table 4, together with their corresponding standard errors. These $\mathrm{T}$ index values equal the probability that two randomly selected companies from within the same country are comparable for each issue. Table 6 provides results for international comparability (overall, within and between country comparisons). These reflect the situation where the pair of companies randomly selected for comparison has no restriction (overall), must belong to the same country (within), and must belong to different countries (between). Tables 5 and 7 correspond to Tables 4 and 6 respectively, but with the additional restriction that the two companies compared must belong to the same industry. Table 8 provides a synthesis of the conclusions to H0, indicating whether the level of comparability is lower or higher when the US companies are included with the European companies, with changes that are statistically significant $(p<.05)$ in bold. These results are discussed by issue below before a summary of the results overall. Unless otherwise stated quoted results refer to those unconditional on industry as results are generally similar. 
Table 3. Measurement policy choice under IFRS and US GAAP

\begin{tabular}{|c|c|c|c|c|c|c|}
\hline Issues & France & Germany & Italy & UK & US & Total \\
\hline \multicolumn{7}{|l|}{ 1) Income statement } \\
\hline 1a) inclusion of a line & 34 & 37 & 24 & 34 & 16 & 145 \\
\hline 1b) not inclusion & 16 & 13 & 26 & 16 & 34 & 105 \\
\hline \multicolumn{7}{|l|}{ 2) Income statement } \\
\hline 2a) by function & 34 & 29 & 8 & 13 & 50 & 134 \\
\hline 2b) by nature & 16 & 15 & 42 & 1 & 0 & 74 \\
\hline 2c) neither & 0 & 6 & 0 & 36 & 0 & 42 \\
\hline \multicolumn{7}{|l|}{ 3) Extraordinary items } \\
\hline 3a) income statement without extraordinary items & 38 & 49 & 36 & 43 & 47 & 213 \\
\hline 3b) with extraordinary items & 12 & 1 & 14 & 7 & 3 & 37 \\
\hline \multicolumn{7}{|l|}{ 4) Terminology adopted } \\
\hline 4a) income statement or statement of income & 48 & 44 & 46 & 47 & 21 & 206 \\
\hline 4b) net Income & 0 & 1 & 0 & 0 & 0 & 1 \\
\hline 4c) operations statement & 0 & 1 & 0 & 2 & 15 & 18 \\
\hline 4d) profit and loss account & 1 & 3 & 4 & 0 & 0 & 8 \\
\hline $4 \mathrm{e})$ results of operations & 0 & 0 & 0 & 0 & 1 & 1 \\
\hline 4f) statement of comprehensive income & 0 & 0 & 0 & 1 & 0 & 1 \\
\hline $4 \mathrm{~g})$ statement of earnings & 1 & 1 & 0 & 0 & 13 & 15 \\
\hline \multicolumn{7}{|l|}{ 5) Financial Statement presentation } \\
\hline 5a) operating cycle criterion & 50 & 50 & 49 & 50 & 0 & 199 \\
\hline 5b) mix & 0 & 0 & 1 & 0 & 48 & 49 \\
\hline 5c) no classification (not applicable) & 0 & 0 & 0 & 0 & 2 & 2 \\
\hline \multicolumn{7}{|l|}{ 6) Statement of Cash Flows } \\
\hline 6a) direct method & 0 & 0 & 0 & 0 & 3 & 3 \\
\hline $6 \mathrm{~b})$ indirect method & 50 & 50 & 50 & 50 & 47 & 247 \\
\hline \multicolumn{7}{|l|}{ 7) PPE (valuation) } \\
\hline 7a) cost model & 46 & 50 & 42 & 50 & 49 & 237 \\
\hline $7 b)$ fair value & 1 & 0 & 1 & 0 & 0 & 2 \\
\hline 7c) mix & 3 & 0 & 7 & 0 & 0 & 10 \\
\hline 7d) not applicable & 0 & 0 & 0 & 0 & 1 & 1 \\
\hline \multicolumn{7}{|l|}{ 8) Identifiable intangible assets } \\
\hline 8a) cost model & 44 & 50 & 48 & 44 & 34 & 220 \\
\hline 8 b) fair value (if there is an active market) & 3 & 0 & 1 & 4 & 0 & 8 \\
\hline 8c) mix & 1 & 0 & 1 & 0 & 0 & 2 \\
\hline 8d) not applicable & 1 & 0 & 0 & 2 & 16 & 19 \\
\hline 8e) not disclosed & 1 & 0 & 0 & 0 & 0 & 1 \\
\hline \multicolumn{7}{|l|}{ 9) Impairment test } \\
\hline 9a) at the end of the year & 6 & 14 & 12 & 15 & 0 & 47 \\
\hline 9b) during the year (at least on a yearly basis) & 3 & 1 & 13 & 2 & 4 & 23 \\
\hline 9c) only upon occurrence of the events & 38 & 30 & 25 & 29 & 38 & 160 \\
\hline 9d) not disclosed & 3 & 5 & 0 & 4 & 8 & 19 \\
\hline \multicolumn{7}{|l|}{ 10) Inventory (valuation) } \\
\hline 10a) FIFO method & 7 & 1 & 6 & 15 & 16 & 45 \\
\hline $10 \mathrm{~b})$ weighted-average cost method & 19 & 32 & 38 & 17 & 3 & 109 \\
\hline 10c) other method & 0 & 0 & 1 & 1 & 0 & 2 \\
\hline 10d) two (or more) methods & 15 & 11 & 5 & 9 & 14 & 54 \\
\hline 10e) LIFO & 0 & 0 & 0 & 0 & 7 & 7 \\
\hline 10f) not applicable & 3 & 0 & 0 & 0 & 3 & 6 \\
\hline 10g) not disclosed & 6 & 6 & 0 & 8 & 7 & 27 \\
\hline \multicolumn{7}{|l|}{ 11) Investment property } \\
\hline 11a) at cost & 7 & 21 & 20 & 5 & 38 & 91 \\
\hline 11b) at fair value & 0 & 2 & 1 & 3 & 0 & 6 \\
\hline 11c) not applicable & 43 & 27 & 29 & 42 & 12 & 153 \\
\hline 11d) not disclosed & 0 & 0 & 0 & 0 & 0 & $\mathbf{0}$ \\
\hline
\end{tabular}


12) Available for sales financial assets

12a) at fair value (to income statement)

$12 b$ ) at fair value (to equity)

12c) mix

12d) not applicable

12e) not disclosed

13) Provision for pension: actuarial gain and losses

13a) to 'Statement of Comprehensive Income'

13b) to income full

13c) corridor method

13d) mix

13e) not disclosed

$\begin{array}{llllll}0 & 0 & 2 & 0 & 1 & \mathbf{3} \\ 36 & 43 & 34 & 40 & 29 & \mathbf{1 8 2} \\ 9 & 0 & 5 & 0 & 7 & \mathbf{2 1} \\ 4 & 7 & 7 & 10 & 10 & \mathbf{3 8} \\ 1 & 0 & 2 & 0 & 3 & \mathbf{6} \\ & & & & & \\ 25 & 26 & 10 & 35 & 4 & \mathbf{1 0 0} \\ 2 & 4 & 22 & 5 & 2 & \mathbf{3 5} \\ 22 & 17 & 18 & 3 & 7 & \mathbf{6 7} \\ 0 & 0 & 0 & 0 & 27 & \mathbf{2 7} \\ 1 & 3 & 0 & 7 & 10 & \mathbf{2 1}\end{array}$

Table 4. National comparability (T indices)

\begin{tabular}{|c|c|c|c|c|c|c|c|c|c|c|}
\hline \multirow{2}{*}{ N. } & \multicolumn{2}{|l|}{ France } & \multicolumn{2}{|c|}{ Germany } & \multicolumn{2}{|l|}{ Italy } & \multicolumn{2}{|l|}{ UK } & \multicolumn{2}{|l|}{$\mathbf{U S}$} \\
\hline & $\mathbf{T}$ & SE & $\mathbf{T}$ & SE & $\mathbf{T}$ & SE & $\mathbf{T}$ & SE & $\mathbf{T}$ & SE \\
\hline 1 & 0.565 & 0.048 & 0.615 & 0.059 & 0.501 & 0.015 & 0.565 & 0.048 & 0.565 & 0.048 \\
\hline 2 & 0.565 & 0.048 & 0.426 & 0.057 & 0.731 & 0.070 & 0.068 & 0.033 & 1.000 & 0.000 \\
\hline 3 & 0.635 & 0.062 & 0.961 & 0.037 & 0.597 & 0.056 & 0.759 & 0.070 & 0.887 & 0.058 \\
\hline 4 & 0.922 & 0.051 & 0.779 & 0.076 & 0.853 & 0.063 & 0.886 & 0.060 & 0.334 & 0.026 \\
\hline 5 & 1.000 & 0.000 & 1.000 & 0.000 & 0.980 & 0.019 & 1.000 & 0.000 & 0.922 & 0.053 \\
\hline 6 & 1.000 & 0.000 & 1.000 & 0.000 & 1.000 & 0.000 & 1.000 & 0.000 & 0.887 & 0.058 \\
\hline 7 & 0.905 & 0.045 & 1.000 & 0.000 & 0.836 & 0.050 & 1.000 & 0.000 & 1.000 & 0.000 \\
\hline 8 & 0.837 & 0.065 & 1.000 & 0.000 & 0.942 & 0.041 & 0.859 & 0.061 & 1.000 & 0.000 \\
\hline 9 & 0.596 & 0.082 & 0.439 & 0.061 & 0.375 & 0.037 & 0.428 & 0.056 & 0.584 & 0.088 \\
\hline 10 & 0.280 & 0.071 & 0.410 & 0.087 & 0.592 & 0.084 & 0.206 & 0.045 & 0.242 & 0.067 \\
\hline 11 & 1.000 & 0.000 & 0.966 & 0.023 & 0.984 & 0.016 & 0.988 & 0.008 & 1.000 & 0.000 \\
\hline 12 & 0.818 & 0.050 & 1.000 & 0.000 & 0.801 & 0.060 & 1.000 & 0.000 & 0.791 & 0.059 \\
\hline 13 & 0.445 & 0.033 & 0.392 & 0.047 & 0.363 & 0.028 & 0.504 & 0.084 & 0.314 & 0.045 \\
\hline
\end{tabular}

Table 5. National comparability ( $\mathrm{T}$ indices) (conditional on industry)

\begin{tabular}{|c|c|c|c|c|c|c|c|c|c|c|}
\hline \multirow{2}{*}{ N. } & \multicolumn{2}{|c|}{ France } & \multicolumn{2}{|c|}{ Germany } & \multicolumn{2}{|l|}{ Italy } & \multicolumn{2}{|l|}{ UK } & \multicolumn{2}{|l|}{ US } \\
\hline & $\mathbf{T}$ & SE & $\mathbf{T}$ & SE & $\mathbf{T}$ & SE & $\mathbf{T}$ & SE & $\mathbf{T}$ & SE \\
\hline 1 & 0.592 & 0.044 & 0.648 & 0.055 & 0.536 & 0.042 & 0.570 & 0.052 & 0.591 & 0.048 \\
\hline 2 & 0.645 & 0.037 & 0.455 & 0.061 & 0.831 & 0.035 & 0.079 & 0.042 & 1.000 & 0.000 \\
\hline 3 & 0.681 & 0.052 & 0.964 & 0.027 & 0.610 & 0.057 & 0.831 & 0.059 & 0.883 & 0.059 \\
\hline 4 & 0.915 & 0.050 & 0.802 & 0.059 & 0.865 & 0.056 & 0.864 & 0.062 & 0.371 & 0.033 \\
\hline 5 & 1.000 & 0.000 & 1.000 & 0.000 & 0.979 & 0.017 & 1.000 & 0.000 & 0.952 & 0.028 \\
\hline 6 & 1.000 & 0.000 & 1.000 & 0.000 & 1.000 & 0.000 & 1.000 & 0.000 & 0.883 & 0.059 \\
\hline 7 & 0.921 & 0.031 & 1.000 & 0.000 & 0.834 & 0.047 & 1.000 & 0.000 & 1.000 & 0.000 \\
\hline 8 & 0.857 & 0.048 & 1.000 & 0.000 & 0.963 & 0.021 & 0.873 & 0.053 & 1.000 & 0.000 \\
\hline 9 & 0.598 & 0.069 & 0.460 & 0.058 & 0.404 & 0.048 & 0.477 & 0.075 & 0.560 & 0.077 \\
\hline 10 & 0.332 & 0.077 & 0.425 & 0.084 & 0.629 & 0.072 & 0.242 & 0.063 & 0.335 & 0.077 \\
\hline 11 & 1.000 & 0.000 & 0.972 & 0.018 & 0.981 & 0.017 & 0.980 & 0.015 & 1.000 & 0.000 \\
\hline 12 & 0.825 & 0.051 & 1.000 & 0.000 & 0.799 & 0.057 & 1.000 & 0.000 & 0.803 & 0.055 \\
\hline 13 & 0.480 & 0.048 & 0.433 & 0.051 & 0.401 & 0.038 & 0.505 & 0.067 & 0.298 & 0.045 \\
\hline
\end{tabular}


Table 6. International comparability ( $\mathrm{T}$ indices) for the four European countries and for Europe and the US

\begin{tabular}{|c|c|c|c|c|c|c|c|c|c|c|c|c|}
\hline \multirow{2}{*}{ N. } & \multicolumn{2}{|c|}{$\begin{array}{l}\text { Overall Country } \\
\text { index (2a) }\end{array}$} & \multicolumn{2}{|c|}{$\begin{array}{l}\text { Standard } \\
\text { error (2a) }\end{array}$} & \multicolumn{2}{|c|}{$\begin{array}{l}\text { Within Country } \\
\text { index ( } 2 \text { b) }\end{array}$} & \multicolumn{2}{|c|}{$\begin{array}{l}\text { Standard } \\
\text { error (2b) }\end{array}$} & \multicolumn{2}{|c|}{$\begin{array}{l}\text { Between Country } \\
\text { index (2c) }\end{array}$} & \multicolumn{2}{|c|}{$\begin{array}{l}\text { Standard } \\
\text { error }(2 c)\end{array}$} \\
\hline & Europe & $\begin{array}{l}\text { Europe } \\
\text { and US }\end{array}$ & Europe & $\begin{array}{l}\text { Europe } \\
\text { and US }\end{array}$ & Europe & $\begin{array}{l}\text { Europe } \\
\text { and US }\end{array}$ & Europe & $\begin{array}{l}\text { Europe } \\
\text { and US }\end{array}$ & Europe & $\begin{array}{l}\text { Europe } \\
\text { and US }\end{array}$ & Europe & $\begin{array}{l}\text { Europe } \\
\text { and US }\end{array}$ \\
\hline 1 & 0.542 & 0.513 & 0.019 & 0.010 & 0.561 & 0.562 & 0.023 & 0.021 & 0.536 & 0.500 & 0.020 & 0.011 \\
\hline 2 & 0.313 & 0.375 & 0.017 & 0.019 & 0.448 & 0.558 & 0.027 & 0.021 & 0.269 & 0.329 & 0.019 & 0.021 \\
\hline 3 & 0.718 & 0.748 & 0.034 & 0.030 & 0.738 & 0.768 & 0.029 & 0.026 & 0.711 & 0.743 & 0.036 & 0.032 \\
\hline 4 & 0.858 & 0.689 & 0.033 & 0.031 & 0.860 & 0.755 & 0.032 & 0.026 & 0.857 & 0.672 & 0.034 & 0.034 \\
\hline 5 & 0.995 & 0.828 & 0.005 & 0.007 & 0.995 & 0.980 & 0.005 & 0.011 & 0.995 & 0.790 & 0.005 & 0.006 \\
\hline 6 & 1.000 & 0.976 & 0.000 & 0.013 & 1.000 & 0.977 & 0.000 & 0.012 & 1.000 & 0.976 & 0.000 & 0.013 \\
\hline 7 & 0.932 & 0.946 & 0.018 & 0.015 & 0.935 & 0.948 & 0.017 & 0.013 & 0.932 & 0.945 & 0.019 & 0.015 \\
\hline 8 & 0.906 & 0.929 & 0.026 & 0.020 & 0.909 & 0.928 & 0.024 & 0.020 & 0.905 & 0.929 & 0.027 & 0.020 \\
\hline 9 & 0.436 & 0.453 & 0.031 & 0.031 & 0.459 & 0.484 & 0.031 & 0.030 & 0.429 & 0.446 & 0.032 & 0.032 \\
\hline 10 & 0.332 & 0.271 & 0.035 & 0.027 & 0.372 & 0.346 & 0.037 & 0.032 & 0.318 & 0.252 & 0.036 & 0.027 \\
\hline 11 & 0.984 & 0.983 & 0.006 & 0.007 & 0.985 & 0.988 & 0.007 & 0.006 & 0.984 & 0.981 & 0.007 & 0.008 \\
\hline 12 & 0.902 & 0.877 & 0.021 & 0.021 & 0.905 & 0.882 & 0.020 & 0.020 & 0.902 & 0.875 & 0.022 & 0.021 \\
\hline 13 & 0.348 & 0.345 & 0.020 & 0.017 & 0.426 & 0.404 & 0.026 & 0.023 & 0.321 & 0.330 & 0.021 & 0.018 \\
\hline
\end{tabular}

Table 7. International comparability ( $\mathrm{T}$ indices) for the four European countries and for Europe and the US (conditional on industry)

\begin{tabular}{|c|c|c|c|c|c|c|c|c|c|c|c|c|}
\hline \multirow{2}{*}{ N. } & \multicolumn{2}{|c|}{$\begin{array}{l}\text { Overall Country } \\
\text { index }(2 a)\end{array}$} & \multicolumn{2}{|c|}{$\begin{array}{l}\text { Standard } \\
\text { error }(2 a)\end{array}$} & \multicolumn{2}{|c|}{$\begin{array}{l}\text { Within Country } \\
\text { index }(2 b)\end{array}$} & \multicolumn{2}{|c|}{$\begin{array}{l}\text { Standard } \\
\text { error }(2 b)\end{array}$} & \multicolumn{2}{|c|}{$\begin{array}{l}\text { Between Country } \\
\text { index (2c) }\end{array}$} & \multicolumn{2}{|c|}{$\begin{array}{l}\text { Standard } \\
\text { error }(2 c)\end{array}$} \\
\hline & Europe & $\begin{array}{l}\text { Europe } \\
\text { and US }\end{array}$ & Europe & $\begin{array}{l}\text { Europe } \\
\text { and US }\end{array}$ & Europe & $\begin{array}{l}\text { Europe } \\
\text { and US }\end{array}$ & Europe & $\begin{array}{l}\text { Europe } \\
\text { and US }\end{array}$ & Europe & $\begin{array}{l}\text { Europe } \\
\text { and US }\end{array}$ & Europe & $\begin{array}{l}\text { Europe } \\
\text { and US }\end{array}$ \\
\hline 1 & 0.549 & 0.523 & 0.020 & 0.012 & 0.585 & 0.586 & 0.024 & 0.022 & 0.536 & 0.506 & 0.023 & 0.014 \\
\hline 2 & 0.344 & 0.399 & 0.020 & 0.020 & 0.492 & 0.598 & 0.022 & 0.018 & 0.288 & 0.343 & 0.023 & 0.022 \\
\hline 3 & 0.721 & 0.753 & 0.032 & 0.029 & 0.770 & 0.794 & 0.026 & 0.024 & 0.703 & 0.741 & 0.036 & 0.032 \\
\hline 4 & 0.856 & 0.683 & 0.032 & 0.029 & 0.863 & 0.761 & 0.029 & 0.024 & 0.853 & 0.662 & 0.034 & 0.033 \\
\hline 5 & 0.995 & 0.828 & 0.004 & 0.006 & 0.995 & 0.986 & 0.004 & 0.007 & 0.995 & 0.784 & 0.005 & 0.006 \\
\hline 6 & 1.000 & 0.975 & 0.000 & 0.013 & 1.000 & 0.976 & 0.000 & 0.012 & 1.000 & 0.975 & 0.000 & 0.014 \\
\hline 7 & 0.931 & 0.943 & 0.018 & 0.015 & 0.940 & 0.952 & 0.014 & 0.011 & 0.928 & 0.941 & 0.019 & 0.016 \\
\hline 8 & 0.913 & 0.936 & 0.022 & 0.017 & 0.919 & 0.936 & 0.020 & 0.016 & 0.911 & 0.936 & 0.024 & 0.018 \\
\hline 9 & 0.446 & 0.458 & 0.031 & 0.031 & 0.486 & 0.502 & 0.032 & 0.030 & 0.431 & 0.445 & 0.033 & 0.033 \\
\hline 10 & 0.336 & 0.281 & 0.032 & 0.026 & 0.400 & 0.387 & 0.037 & 0.033 & 0.312 & 0.252 & 0.033 & 0.025 \\
\hline 11 & 0.983 & 0.981 & 0.007 & 0.007 & 0.984 & 0.987 & 0.007 & 0.006 & 0.983 & 0.980 & 0.007 & 0.008 \\
\hline 12 & 0.903 & 0.879 & 0.020 & 0.020 & 0.907 & 0.885 & 0.019 & 0.019 & 0.902 & 0.877 & 0.021 & 0.021 \\
\hline 13 & 0.362 & 0.354 & 0.020 & 0.018 & 0.457 & 0.424 & 0.027 & 0.023 & 0.326 & 0.335 & 0.023 & 0.019 \\
\hline
\end{tabular}

Table 8. Comparison of $\mathrm{T}$ index values with US included compared to Europe only

\begin{tabular}{|c|c|c|c|c|c|c|c|c|c|}
\hline $\mathrm{N}$ & $\begin{array}{l}\text { Overall } \\
\text { country index }(2 a)\end{array}$ & p-value ${ }^{1}$ & $\mathrm{p}$-value ${ }^{2}$ & $\begin{array}{l}\text { Within } \\
\text { country index (2b) }\end{array}$ & p-value ${ }^{1}$ & p-value ${ }^{2}$ & $\begin{array}{l}\text { Between } \\
\text { country index (2c) }\end{array}$ & p-value ${ }^{1}$ & p-value ${ }^{2}$ \\
\hline 1 & Lower & 0.000 & 0.004 & Higher & 0.479 & 0.459 & Lower & 0.001 & 0.017 \\
\hline 2 & Higher & 0.000 & 0.000 & Higher & 0.000 & 0.000 & Higher & 0.000 & 0.000 \\
\hline 3 & Higher & 0.007 & 0.008 & Higher & 0.016 & 0.067 & Higher & 0.005 & 0.002 \\
\hline 4 & Lower & 0.000 & 0.000 & Lower & 0.000 & 0.000 & Lower & 0.000 & 0.000 \\
\hline 5 & Lower & 0.000 & 0.000 & Lower & 0.128 & 0.117 & Lower & 0.000 & 0.000 \\
\hline 6 & Lower & 0.045 & 0.043 & Lower & 0.045 & 0.043 & Lower & 0.045 & 0.043 \\
\hline 7 & Higher & 0.000 & 0.000 & Higher & 0.000 & 0.000 & Higher & 0.000 & 0.000 \\
\hline 8 & Higher & 0.000 & 0.000 & Higher & 0.000 & 0.000 & Higher & 0.000 & 0.000 \\
\hline 9 & Higher & 0.144 & 0.306 & Higher & 0.099 & 0.269 & Higher & 0.127 & 0.200 \\
\hline 10 & Lower & 0.000 & 0.001 & Lower & 0.049 & 0.217 & Lower & 0.000 & 0.001 \\
\hline 11 & Lower & 0.039 & 0.109 & Higher & 0.002 & 0.008 & Lower & 0.020 & 0.046 \\
\hline 12 & Lower & 0.028 & 0.026 & Lower & 0.026 & 0.029 & Lower & 0.030 & 0.033 \\
\hline 13 & Lower & 0.382 & 0.176 & Lower & 0.011 & 0.000 & Higher & 0.259 & 0.268 \\
\hline
\end{tabular}

${ }^{1}$ p-value based on indices calculated comparing pairs of companies regardless of industry (unconditional).

${ }^{2}$ p-value based on indices calculated comparing pairs of companies within the same industry (conditional on industry).

Values in bold are statistically significant at the 0.05 level. Lower indicates comparability with the USA is lower than comparability without the USA. 


\section{Income Statement (item 1)}

IFRS does not contain any strict requirements for the presentation format, while US GAAP offers two different alternatives: the single-step (that is 'not inclusion of a line') and multiple-step formats (that is 'inclusion of a line').

The 'inclusion of a line' (the possibility to highlight a first partial result in the income statement), is the option most followed by each of the European countries but not for US companies (Table 3). Since comparability within each country (Table 4) are similar, inclusion of the US has minimal impact on within country comparability however overall and between country comparability decreases significantly when the US is included (Table 8). Thus H0 is rejected for international comparability (overall and between indices) but comparability within countries is similar.

\section{Income Statement (item 2)}

US GAAP requires the classification of expenses by function, while IFRS offers two different alternatives: by nature or function, clarifying that in the event of the latter the preparer must provide additional information on the nature of expenses.

For this item, the UK statements show by far the lowest national comparability ( $\mathrm{T}=0.068)$. This is predominantly due to the 36 UK financial statements using neither of these two reclassification methods.

The obligation in US financial statements to reclassify the income statement 'by function' (national comparability always equal to 1$)$ significantly $(\mathrm{p}=.000)$ increases all comparability indicators (overall, within and between country index, both unconditionally and conditional on industry) leading to a rejection of $\mathrm{H} 0$.

\section{Extraordinary Items (item 3)}

Both IFRS and US GAAP permit the inclusion of unusual or infrequent items in the Income Statement, but IFRS prohibits the presentation of non-recurring income and expense. US GAAP permits extraordinary items, but they must fall within a very restrictive definition.

'Income statement without extraordinary items' prevails in the statements of all countries (France $76 \%$, Germany $98 \%$, Italy $72 \%$, United Kingdom $86 \%$, US $94 \%$ ). The high national comparability of US ( 0.887 unconditional on industry) significantly increases nearly all comparability indices, leading to a rejection of $\mathrm{H} 0$.

\section{Terminology (item 4)}

At least $88 \%$ of companies within each European country use 'income statement or statement of income' but only $42 \%$ of US companies use this terminology. The diversity of terminology used in the US results in significantly lower national comparability $(\mathrm{T}=0.334)$, with $30 \%$ of US companies using 'operations statements' and $26 \%$ using 'statement of earnings'. Inclusion of the US significantly lowers all indices of comparability, strongly rejecting $\mathrm{H} 0$.

\section{Financial Statement presentation (item 5)}

IAS 1 does not require a specific format for the balance sheet but does require the presentation of specific accounting items. The required basis of presentation is current and non-current classification, but the financial and mixed methods are permitted as well, when cash-based presentation is more reliable and meaningful. On the basis of S-X regulations, there are no significant discrepancies with that provided for by IAS 1, although US GAAP financial statements generally adopt a format with separate, comparative sections in which assets are compared with liabilities. The items are similar to those provided for by IAS 1 but certain aspects arise, regarding, in particular the balance sheet presentation: in US GAAP financial statements, the preparer may choose between a classified and unclassified balance sheet, and may apply the increasing or declining liquidity method.

All European companies use 'operating cycle criterion' except for one Italian company, producing extremely high levels of comparability (overall $\mathrm{T}=0.995$ for European countries). This method, however, is never used in the US where $96 \%$ of companies use 'mixed criterion'. This large difference between European countries and the US results in significantly lower international comparability when the US is included. Hence HO is rejected, except for the within country indices where the difference is not statistically significant.

\section{Statement of cash flows (item 6)}

Both IFRS and US GAAP permit the application of the direct and indirect methods in the presentation of the Statement of Cash Flows. The difference between the two sets of standards is that, under IFRS, only the indirect method entails the reconciliation of net profit and cash flows from operating activities, while US GAAP requires 
this reconciliation for both methods.

All European companies use the 'indirect' method, resulting in perfect comparability ( $\mathrm{T}=1)$. The majority (94\%) of US companies also use the 'indirect' method but three companies use the 'direct' method, resulting in significantly lower comparability when the US is included, and hence rejection of $\mathrm{HO}$.

\section{Property, plant and equipment (PPE) (item 7)}

All US companies use the 'cost model' (national comparability equal to 1) as US GAAP requires this method. Financial statements of France, Germany, Italy and the UK strongly converge towards this option, leading to high comparability in general. Furthermore, all comparability indicators (overall, within and between country index) are significantly $(\mathrm{p}=.000)$ higher when the US is included, strongly rejecting H0.

\section{Identifiable intangible assets (item 8)}

IFRS and US GAAP share the same definition of this accounting item, as well as the same identification and recognition criteria. They both require that costs be reliably measurable and generate estimated future economic benefits. Certain cost categories cannot be capitalized under either set of accounting standards. First, the preparer must distinguish between the two main methods of acquisition: if the asset was acquired externally (separately or as part of a business combination) or if it was generated internally.

As for measurement after initial recognition, IAS 38 permits the revaluation of intangible assets at fair value if the existence of an active market can be demonstrated. This option is not permitted by US GAAP.

The 'cost model' is the only option under US GAAP, leading to national comparability equal to 1 for the US. This issue is not applicable for $32 \%$ of the USA companies, but it is applicable to almost all European companies. The financial statements of European companies strongly converge towards the 'cost model', with high national comparability ( $\mathrm{T}=0.837$ for France; $\mathrm{T}=1.000$ for Germany; $\mathrm{T}=0.942$ for Italy; $\mathrm{T}=0.859$ for United Kingdom).

Thus the inclusion of the US significantly $(\mathrm{p}=.000)$ increases all comparability indicators, leading to the rejection of $\mathrm{H} 0$.

\section{Impairment test (of long-lived assets): the timing aspect (item 9)}

This item analyses when impairment is performed. Although both US GAAP and IFRS prescribe impairment of long-lived assets upon occurrence of the events (Table 2), some companies use different methods (Table 3). National comparability (Table 4 and 5) of the European companies is therefore not very high ( $\mathrm{T}=0.596$ for France; $\mathrm{T}=0.439$ for Germany; $\mathrm{T}=0.375$ for Italy; $\mathrm{T}=0.428$ for United Kingdom;), thus, by also including US companies, the overall comparability increases, since the preferred option ('only upon occurrence of the events ') is the same in European companies. These increases in comparability are however not statistically significant and hence there is insignificant evidence to reject $\mathrm{H} 0$.

\section{Inventory (item 10)}

The IFRSs do not permit the use of the LIFO method. If inventories are written down and there is an increase in value, a revaluation must be performed. In this respect, US GAAP is substantially in line with IFRS, as they propose the use of the lower of cost and market value.

Market value is identified as current replacement cost, which must not exceed net realizable value or fall below it, net of normal profit margins. Unlike the IFRSs, goods may not be written back after being written down.

National comparability is low for all countries and often the lowest of all the items. Although LIFO is permitted under US GAAP, only $14 \%$ of US companies use this option. The inclusion of US companies lowers all the comparability indices, and these changes are nearly always statistically significant. Hence hypothesis H0 is rejected.

\section{Investment property (item 11)}

While IFRS provides a choice between amortized cost and fair value, US GAAP requires the use of amortized cost. Compliance within the US results in perfect national comparability $(\mathrm{T}=1)$ while comparability in European nations is also high ( $T$ exceeding 0.96 ) with amortized cost being the most popular method in all countries. Note that although all US companies use amortized cost, the dominate method in Europe, international comparability overall and between countries actually decreases significantly when the US is included, leading to a rejection of H0. This occurs because European companies are more likely to have investment property not applicable, resulting in high comparability, while US companies tend to use cost, which is not comparable to the European companies using fair value and hence lowers comparability. Within country comparability, however, is significantly higher with the US due to the high comparability within the US. 


\section{Available-for-sale (AFS) financial assets (item 12)}

IAS 39 distinguishes between four different categories of financial assets: financial assets held for trading, held to maturity financial assets, loans and receivables and available for sale financial assets. This item relates to the measurement criterion for available for sale financial assets, which include all bonds and equities not included in the other categories (Note 3).

Fair value (to equity) is the prevalent method in all countries, but less so for the US (58\% of companies compared to from $68 \%$ in Italy to $86 \%$ in Germany). This lack of concentration on the dominant method by US companies results in significantly lower comparability indices when the US is included, leading to a rejection of $\mathrm{H} 0$.

\section{Provision for pension: actuarial gains and losses (item 13)}

IAS 19 analyzes all employee benefits: these benefits are recognized through a specific provision under balance sheet liabilities, while each year, an amount determined by three separate components is taken to profit or loss. The first component is the increase in the provision, while the second is interest expense due to the increase in the present value of the provision to reflect the passage of time, and the third, which constitutes one of the issues under analysis, is due to changes in the financial and demographic assumptions used for actuarial purposes. IAS 19 offers two different alternatives for the full recognition of actuarial gains and losses in profit or loss: 1) changes due to the change in actuarial assumptions are taken to an equity reserve, where, in accordance with IAS 1 , they will be considered in a specific section of the Statement of Comprehensive Income as Other Comprehensive Income (OCI);2) in place of the full recognition of actuarial gains and losses, the corridor approach may be adopted, in which only the difference in excess of $10 \%$ of the present liability to employees for defined-benefit plans is taken to profit or loss. The IASB has a project on this issue entitled 'Post-employment benefits' and in relation to which it published a Discussion Paper in 2008.

US GAAP distinguishes between two alternatives: the recognition of actuarial gains and losses outside profit or loss and the recognition of actuarial gain and losses in profit or loss. In the former, US GAAP differs from IFRS as it provides for inclusion in the income statement and gains and losses can only be subsequently taken to (in the OCI) within certain limits. Subsequently, these gains and losses are amortized to profit or loss. In the latter, US GAAP is similar to IFRS, except for the corridor limits.

National comparability is relatively low in all European countries due to the use of several methods, however in the US it is low due to $54 \%$ of the companies using a mix of methods and $20 \%$ not disclosing their method. This results in low national comparability of $\mathrm{T}=0.314$ in the US (compared to European comparability ranging from 0.392 for Germany to 0.504 for the UK). The low level of comparability in the US significantly lowers comparability within countries when the US is included, but does not significantly change the overall or between country measures of comparability. Thus evidence is only provided to reject $\mathrm{HO}$ for comparisons of companies within the same country.

\section{Conclusion}

This research investigates comparability of the consolidated financial statements of the largest European (France, Germany, Italy, the UK) and US companies. The time reference is the year 2009, the first year that was affected by the GFC (Global Financial Crisis) and by the joint actions of the IASB and FASB in response to the crisis, particularly as regards financial instruments and fair value accounting. The T index framework (Taplin, 2004, 2011) was used to measure comparability. The analysis initially focused on financial comparability of European companies. Subsequently, the sample was expanded to include American companies in order to assess the resulting change in comparability.

Results are presented both unconditionally and conditional on industry to ascertain the impact of only comparing companies that operate within the same industry. This is an important methodological advance, as it has been argued that only companies operating in similar circumstances should be expected to have comparable accounts in order to achieve full comparability and after country effects industry has been shown to be the next most important determinant of accounting policy choice (Jaafar \& McLeay, 2007). While it is true that comparability is generally higher if only companies within the same industry sector are compared, this effect is generally small and overall conclusions are similar.

The main objective of this study is to provide a judgment on the comparability of financial statements prepared under IFRS and US-GAAP: this issue is of particular interest in view of the effects that this will induce not only on the American and European but also on global financial markets. The main results of our research (summarized in Table 8) cause the following considerations and implications. 
First, differences in the within country comparability values, with and without the US, amount to relating the comparability within the US with comparability within European countries. Table 8 suggests comparability can be both significantly higher (5 items) and significantly lower (5 items) within the US compared to within European countries. Thus conclusions concerning US GAAP or IFRS producing more comparable financial statements within a jurisdiction differ by item. To maximize comparability, any decision by standard setters to use IFRS or US GAAP should be made on a case by case basis for each item separately.

Second, for 7 of the 13 items (Table 8), both overall and between country international comparability is significantly lower if the US is included with the European countries. This result reflects the serious difficulties linked to the achievement of real convergence even in relation to those items for which IASB and FASB are committed to the implementation of convergence projects (such as the plan for the IAS 1, revised 2007 regarding the Financial Statement Presentation).

Third, for 4 of the 13 items international comparability, both overall and between countries, is significantly higher if the US is included. This result might be unexpected due to differences in the two standards. This significantly higher comparability generally occurs where options are provided under IFRS but not under US GAAP, but the US GAAP standard is already a common choice for European companies. In particular, this is the case for item 2 (income statement), item 7 (valuation of PPE) and item 8 (identifiable intangible assets). In other words, among European companies there was a trend to choose the IFRS option required under US GAAP. Thus, although items should be considered on a case by case basis for international comparability as well as within country comparability, it appears modifying IFRS to be consistent with US GAAP has merit for many items if the aim is to increase international comparability.

Finally, this variation in conclusions by item is not explained by whether the item relates to presentation (items 1 to 6) or measurement (items 7 to 13). Both types of items have approximately equal numbers of items with higher or lower comparability when the US is included compared to when it is excluded. However, the items that have suffered the strongest decrease in comparability due to the inclusion of the US are item 4 (terminology adopted) and item 5 (Financial statement presentation). Both these items are unable to alter financial statement values.

One inference that can be drawn from these mixed results is while low comparability between company accounts is partially driven by different standards and national characteristics, a dominant factor in this low comparability is due to a lack of comparability between companies within the same countries. For example, the two items with the lowest overall comparability across these five countries are items 10 (inventory valuation) and 13 (provision for pension). The low comparability for these items on all measures, including national comparability within each country, suggests low comparability is driven by a lack of comparability within each country rather than from inconsistency between countries. This suggests the focus on differences in countries may be misdirected. It is possible there are legitimate reasons for companies to use different methods depending on their circumstances, however the results conditional on industry demonstrate that restricting comparisons to companies within the same industry produces similar results. Jaafar and McLeay (2007) showed that after country the next most important company characteristic was industry, with other factors such as size and listing status having minimal impact on the choice of accounting method. Therefore it is unclear whether any other company characteristics can explain this choice.

These conclusions hold for many items where comparability is higher (eg. items 6, 7,11 and 12). Comparability could be improved by removing options within IFRS and/or US GAAP but national differences do not play a major role. In these instances, comparability is lowered by only a few companies deviating from the most common method. As before, only comparing companies within the same industry only improves comparability slightly, suggesting the choice of different options chosen because companies operate in different circumstances does not justify this variation in method used.

Item 5 (financial statement presentation) was the major item where comparability was high within Europe, high within the US, but low between these jurisdictions. In this case the need for an alignment between IFRS and US GAAP is most evident. Other items where reconciliation between IFRS and US GAAP would improve comparability can be interpreted as resulting from one of the two standards allowing options: either IFRS (items $2,3,9$ ) or US GAAP (items 4 ). Thus, in all cases except item 5 , lack of comparability may be driven by options within a standard rather than by explicit differences between standards. The key issue is whether options are allowed within either or both standards rather than fundamental differences between standards. The need to eliminate options has previously been suggested in the literature, for example: 'In our view the disadvantages for systematic differences outweigh the advantages of having options, so we encourage the IASB to continue its 
efforts to remove options' (Kvaal \& Nobes 2010, p. 186).

A recent line of research provides evidence of improvements in comparability from IFRS adoption by defining comparability in terms of stronger relationships between financial outputs such as earnings, stock price and cash flow (De Franco et al., 2011; Barth, Landsman, Lang, \& Williams, 2012). This paper complements this research by taking a more direct approach of examining individual accounting items. This provides insights into where in financial statements comparability is low and the extent to which this is driven by differences between IFRS and US GAAP or driven by options available within either or both standards. While disregarding all the political and economic implications of the adoption of IFRS in the US, it is essential to assess the potential impact of IFRS adoption on the quality and comparability of US reporting practices, the ensuing capital market effects and the potential costs of switching from US GAAP to IFRS (Hail et al., 2010). It is clear that a greater global comparability of financial statements lead to a greater ease in movement of capital and thus in investment opportunities (Schipper, 2005; Joos \& Leung, 2013).

Future research may extend and enhance this study in several ways, including: extension to additional countries; extension to smaller companies; examining more recent time periods for more recent changes; and considering other factors that may influence accounting policy choice. After country, time period and industry sector considered in this study, the size of the company may influence policy choice (size of company was controlled for in this study be selecting the largest companies in each country). Future work may sample smaller companies as well and segment companies into small, medium and large companies before calculating $\mathrm{T}$ indices conditional on size instead of (or as well as) conditional on industry sector.

\section{References}

A Securities and Exchange Commission. (2011). Work plan for the Consideration of Incorporating International Financial Reporting Standards into the Financial Reporting System for U.S. Issuers. Exploring a Possible Method of Incorporation, 1-24. $\quad$ Retrieved from https://www.sec.gov/spotlight/globalaccountingstandards/ifrs-work-plan-paper-052611.pdf

A Securities and Exchange Commission. (2012). Work plan for the Consideration of Incorporating International Financial Reporting Standards into the Financial Reporting System for U.S. Issuers. Final Staff Report, July 13, 1-127. Retrieved from https://www.sec.gov/spotlight/globalaccountingstandards/ifrs-work-plan-final-report.pdf

Abd-Elsalam, O. H., \& Weetmar, P. (2003). Introducing International Accounting Standards to an emerging capital market: Relative familiarity and language effect in Egypt. Journal of International Accounting, Auditing and Taxation, 12(1), 63-84. http://dx.doi.org/10.1016/S1061-9518(03)00002-8

Aboody, D., Barth, M., \& Kasnik, R. (1999). Revaluations of fixed assets and future firm performance: Evidence from the UK. Journal of Accounting and Economics, 26(1-3), 149-178. http://dx.doi.org/10.1016/S0165-4101(98)00040-8

Adams, C. A., Weetman, P., \& Gray, S. (1993). Reconciling national with international accounting standards. European Accounting Review, 2(3), 471-494. http://dx.doi.org/10.1080/09638189300000048

Adhikari, A., \& Emenyonu, E. (1997). Accounting for business combinations and foreign currency translation, an empirical comparison of listed companies from developed economies. Advances in International Accounting, 10, 45-62.

Aisbitt, S. (2001). Measurement of Harmony of Financial Reporting within and between Countries: The Case of Nordic Countries. European Accounting Review, 10(1), 51-72. http://dx.doi.org/10.1080/09638180122041

Alford, A., Jones, J., Leftwich, R., \& Zmijewski (1993). The relative informativeness of accounting disclosures in different countries. Journal of Accounting Research, 31(Supplement), 183-223. http://dx.doi.org/10.2307/2491170

Al-Shammari, B., Brown, P., \& Tarca, A. (2008). An investigation of compliance with International Accounting Standards by listed companies in the Gulf co-operation council member states. The International Journal of Accounting, 43, 425-447. http://dx.doi.org/10.1016/j.intacc.2008.09.003

Amir, E., Harris, T. S., \& Venuti, E. K. (1993). A comparison of the value-relevance of US versus non-US-GAAP accounting measures using form 20-F reconciliations. Journal of Accounting Research, 31, 230-264. http://dx.doi.org/10.2307/2491172

Archer, S., Delvaille, P., \& McLeay, S. (1995). The measurement of harmonization and the comparability of financial statement items, within-country and between-country effects. Accounting and Business Research, 
25(98), 67-80. http://dx.doi.org/10.1080/00014788.1995.9729930

Archer, S., Delvaille, P., \& McLeay, S. (1996). A statistical model of international accounting harmonization. Abacus, 32(1), 1-29. http://dx.doi.org/10.1111/j.1467-6281.1996.tb00448.x

Armstrong, C., Barth, M., Jagolinzer, A., \& Riedl, E. (2010). Market Reaction to the Adoption of IFRS in Europe. The Accounting Review, 85, 31-61. http://dx.doi.org/10.2308/accr.2010.85.1.31

Ashbaugh, H., \& Olsson, P. (2002). An exploratory study of the valuation properties of cross-listed firms' IAS and US GAAP earnings and book values. The Accounting Review, 77(1), 107-127. http://dx.doi.org/10.2308/accr.2002.77.1.107

Ashbaugh, H., \& Pincus, M. (2001). Domestic accounting standards, international accounting standards, and predictability of earnings. Journal of Accounting Research, 39, 417-434. http://dx.doi.org/10.1111/1475-679X.00020

Astami, E. W., Tower, G., Rusmin, R., \& Taplin, R. (2006). An Exploration of the Attributes of International Harmonization Indices Using the T-Index. Journal of Contemporary Issues in Business and Government, 12(2), 47-66.

Baker, C. R., \& Barbu, E. M. (2007). Trends in research on international accounting harmonization. The International Journal of Accounting, 42(3), 272-304. http://dx.doi.org/10.1016/j.intacc.2007.06.003

Bandyopadhyay, S. P., Hanna, J. D., \& Richardson, G. (1994). Capital market effects of American-Canadian GAAP differences. Journal of Accounting Research, 32, 262-277. http://dx.doi.org/10.2307/2491285

Barniv, R., \& Fetyko, D. (1997). Attitudes of CPAs and financial executives toward harmonization of international accounting standards: An analytical and empirical examination. Journal of Accounting and Economics, 6(2), 149-169.

Barth, M. E., \& Clinch, G. (1996). International accounting differences and their relation to share prices, evidence from UK, Australian and Canadian firms. Contemporary Accounting Research, 13(1), 135-170. http://dx.doi.org/10.1111/j.1911-3846.1996.tb00495.x

Barth, M. E., Landsman, W. R., \& Lang, M. (2008). International Accounting Standards and Accounting Quality. Journal of Accounting Research, 46(3), 467-498. http://dx.doi.org/10.1111/j.1475-679X.2008.00287.x

Barth, M. E., Landsman, W. R., Lang, M. H., \& Williams, C. (2012). Are IFRS-Based and US GAAP-Based accounting amounts comparable? Journal of Accounting and Economics, 54(1), 68-93. http://dx.doi.org/10.1016/j.jacceco.2012.03.001

Baxter, W. T. (1981). Accounting Standards-Boon or Curse? Accounting and Business Research, 12(45), 3-10. http://dx.doi.org/10.1080/00014788.1981.9728783

Beattie, V., Fearnely, S., \& Hines, T. (2008). Does IFRS undermine UK reporting integrity. Accountancy Magazine, 142, 56-57.

Bhattacharya, U., Daouk, H., \& Welker, M. (2003). The world price of earnings opacity. The Accounting Review, 78, 641-678. http://dx.doi.org/10.2308/accr.2003.78.3.641

Bhoocha, A., \& Stansell, S. R. (1990). A study of international financial market integration: An examination of the US, Hong Kong and Singapore markets. Journal of Business, Finance, and Accounting, 17(2), 193-212. http://dx.doi.org/10.1111/j.1468-5957.1990.tb00557.x

Biddle, G. C., \& Saudagaran, S. M. (1991). Foreign stock listings: Benefits, costs and the accounting policy dilemma. Accounting Horizons, 5(3), 69-80.

Boross, Z., Clarkson, A. H., Fraser, M., \& Weetman, P. (1995). Pressures and conflicts in moving towards harmonization of accounting in Hungary. The European Accounting Review, 4(4), 713-737. http://dx.doi.org/10.1080/09638189500000046

Bradsaw, M., Callahan, C., Ciesielski, J., Gordon, E. A., Hodder, L., Hopkins, P. E., Kohlbeck, M., Laux, R., McVay, S., Stober, T., Stocken, P., \& Yohn, T. L. (2010). Response to the SEC's Proposed Rule-Roadmap for the Potential Use of Financial Statements Prepared in Accordance with International Financial Reporting Standards (IFRS) by U.S. Issuers. Accounting Horizons, 24(1), 117-128. http://dx.doi.org/10.2308/acch.2010.24.1.117

Bradshaw, M. T., Bushee, B. J., \& Miller, G. S. (2004). Accounting choice, home bias, and US investment in non-US firms. Journal of Accounting Research, 42(5), 795-841. 
http://dx.doi.org/10.1111/j.1475-679X.2004.00157.x

Bradshaw, M., Callahan, C., Ciesielski, J., Gordon, E., Kohlbeck, M., Hodder, L., Hopkins, P. E., Laux, R., McVay, S., Stober, T., Stocken, P., \& Teri Lombardi, Y. (2010). The American Accounting Association's Financial Reporting Policy Committee's response to the Preliminary Views on Financial Statement Presentation. Accounting Horizons, 24(2), 279-296. http://dx.doi.org/10.2308/acch.2010.24.2.279

Brennan, N. M., \& Connell, B. (2000). Intellectual Capital: Current Issues and Policy Implications. Journal of Intellectual Capital, 1(3), 206-240. http://dx.doi.org/10.1108/14691930010350792

Cairns, D., (2010). Accounting standards and the financial crisis. Accountancy Magazine, 67. Retrieved from http://www.accountancymagazine.com

Cairns, D., Massoudi, D., Taplin, R., \& Tarca, A. (2011). IFRS fair value measurement and accounting policy choice in the United Kingdom and Australia. British Accounting Review, 43, 1-21. http://dx.doi.org/10.1016/j.bar.2010.10.003

Callagan, S., \& Treacy, M. (2007). Towards convergence. IFRS to US GAAP Differences. Accountancy Ireland, 39(6), 10-14.

Cañibano, L., \& Mora, A. (2000). Evaluating the statistical significance of de facto accounting harmonization: A study of European global players. European Accounting Review, 9(3), 349-369. http://dx.doi.org/10.1080/09638180020017113

Chaplinski, S., \& Ramchand, L. (2000). The Impact of Global Equity Offerings. The Journal of Finance, 55(6), 2767-2789. http://dx.doi.org/10.1111/0022-1082.00306

Chen, S., Sun, Z., \& Wang, Y. (2002). Evidence from China on Whether Harmonized Accounting Standards Harmonize Accounting Practices. Accounting Horizons, 16(3), 183-197. http://dx.doi.org/10.2308/acch.2002.16.3.183

Choi, F. D. S., \& Levich, R. M. (1991). Behavioral effect of international accounting diversity. Accounting Horizons, 1-13.

Cooke, T. E. (1989). Voluntary corporate disclosure by Swedish companies. Journal of International Financial Management and Accounting, 1(2), 171-195. http://dx.doi.org/10.1111/j.1467-646X.1989.tb00009.x

Cooke, T. E. (1991). An assessment of voluntary disclosure in the annual reports of Japanese corporations. The International Journal of Accounting, 26(3), 174-189.

Cooke, T. E. (1993). The impact of accounting principles on profits: The US versus Japan. Accounting and Business Research, 23(92), 460-476. http://dx.doi.org/10.1080/00014788.1993.9729891

Daske, H., Hail, L., Leuz, C., \& Verdi, R. (2008). Mandatory IFRS Reporting around the World: Early Evidence on the Economic Consequences. Journal of Accounting Research, 46(5), 1085-1142. http://dx.doi.org/10.1111/j.1475-679X.2008.00306.x

De Franco, G., Kothari, S. P., \& Verdi, R. S. (2011). The Benefits of Financial Statement Comparability. Journal of Accounting Research, 49(4), 895-931. http://dx.doi.org/10.1111/j.1475-679X.2011.00415.x

Ding, Y. D., Stolowy, H., \& Tenenhaus, M. (2003). "Shopping around" for accounting practices: The financial statement presentation of French groups. Abacus, 39(1), 42-65. http://dx.doi.org/10.1111/1467-6281.00119

Ding, Y., Hope, O., Jeanjean, T., \& Stolowy, H. (2007). Differences domestic accounting standards and IAS: Measurement, determinants and implications. Journal of Accounting and Public Policy, 26(1), 1-38. http://dx.doi.org/10.1016/j.jaccpubpol.2006.11.001

Dumontier, P., \& Raffournier, B. (2002). Accounting and capital markets: A survey of the European evidence. European Accounting Review, 11(1), 119-151. http://dx.doi.org/10.1080/09638180220124761

Durand, R. B., \& Tarca, A. (2005). The Impact of US GAAP Reconciliation Requirements on Choice of Foreign Stock Exchange for Firms from Common Law and Code Law Countries. European Accounting Review, 14(4), 789-813. http://dx.doi.org/10.1080/09638180500108536

Dye, R. A., \& Sunder, S. (2001). Why not allow FASB and IASB Standards to Compete in the U.S.? Accounting Horizons, 15(3), 257-271. http://dx.doi.org/10.2308/acch.2001.15.3.257

Erchinger, H., \& Melcher, W. (2007). Convergence between US GAAP and IFRS: Acceptance of IFRS by the US Securities and Exchange Commission (SEC). Accounting in Europe, 4(2), 123-139. http://dx.doi.org/10.1080/17449480701727908 
Erikson, D., Esplin, A., \& Maines, L. A. (2009). One world-One accounting. Business Horizons, 52(6), 531-537. http://dx.doi.org/10.1016/j.bushor.2009.06.006

Frost, C. A., \& Pownall, G. (1994). Accounting disclosure practices in the United States and the United Kingdom. Journal of Accounting Research, 32(1), 75-102. http://dx.doi.org/10.2307/2491388

Glaum, M. \& Street, D. L. (2003). Compliance with the Disclosure Requirements of Germany's New Market: IAS Versus US GAAP. Journal of International Financial Management and Accounting, 14(1), 64-100. http://dx.doi.org/10.1111/1467-646X.00090

Glaum, M. (2000). Bridging the GAAP, the changing attitude of German managers towards Anglo-American accounting and accounting harmonization. Journal of International Financial Management and Accounting, 11(1), 23-47. http://dx.doi.org/10.1111/1467-646X.00054

Grove, H. D., \& Bazley, J. D. (1993). Disclosure strategies for harmonization of international accounting standards. The International Journal of Accounting, 28(2), 116-128.

Guenther, D. A., \& Young, D. (2000). The association between financial accounting measures and real economic activity: A multinational study. Journal of Accounting and Economics, 29(1), 53-72. http://dx.doi.org/10.1016/S0165-4101(00)00013-6

Hail, L., Leuz, C., \& Wysocki, P. (2010a). Global Accounting Convergence and the Potential Adoption of IFRS by the U.S. (Part I): Conceptual Underpinnings and Economic Analysis. Accounting Horizons, 24(3), 355-394. http://dx.doi.org/10.2308/acch.2010.24.3.355

Hail, L., Leuz, C., \& Wysocki, P. (2010b). Global Accounting Convergence and the Potential Adoption of IFRS by the U.S. (Part II): Political Factors and Future Scenarios for U.S. Accounting Standards. Accounting Horizons, 24(4), 567-588. http://dx.doi.org/10.2308/acch.2010.24.4.567

Harris, M. S., \& Muller, K. A. (1999). The market valuation of IAS versus US GAAP accounting measures using Form 20-F reconciliations. Journal of Accounting and Economics, 26, 285-312. http://dx.doi.org/10.1016/S0165-4101(99)00003-8

Harris, T., Lang, M., \& Moller, H. (1994). The Value Relevance of German Accounting Measures: An Empirical Analysis. Journal of Accounting Research, 32(2), 285-312. http://dx.doi.org/10.2307/2491281

Haverty, J. L. (2006). Are IFRS and U.S. GAAP converging?: Some evidence from People's Republic of China companies listed on the New York Stock Exchange. Journal of International Accounting Auditing and Taxation, 15(1), 48-71. http://dx.doi.org/10.1016/j.intaccaudtax.2006.01.004

Hellman, N. (1993). A comparative analysis of the impact of accounting differences on profits and return on equity: Differences between Swedish practice and US GAAP. European Accounting Review, 2(3). http://dx.doi.org/10.1080/09638189300000049

Henry, E., Lin, S., \& Yang, Y. (2009). The European-U.S. "GAAP Gap": IFRS to U.S. GAAP Form 20-F Reconciliations. Accounting Horizons, 23(2), 121-150. http://dx.doi.org/10.2308/acch.2009.23.2.121

Herrmann, D., \& Thomas, W. (1995). Harmonization of accounting measurement practices in the European Community. Accounting and Business Research, 25(100), 253-265. http://dx.doi.org/10.1080/00014788.1995.9729914

Hoogervorst, H., \& Seidman, L. F. (2012). IASB-FASB Update Report to the FSB plenary on Accounting Convergence. Retrieved from http://www.ifrs.org

Hung, M. (2000). Accounting standards and value relevance of financial statements: An international analysis. Journal of Accounting and Economics, 30(3), 401-420. http://dx.doi.org/10.1016/S0165-4101(01)00011-8

IASCF. (2005). Constitution, London, International Accounting Standards Committee Foundation, para. 2 (a). Retrieved from http://www.iasplus.com/en/binary/restruct/0504constrevupdate.pdf

Jaafar, A., \& McLeay, S. (2007). Country Effects and Sector Effects on the Harmonization of Accounting Policy Choice. Abacus, 43(2), 156-189. http://dx.doi.org/10.1111/j.1467-6281.2007.00224.x

Jamal, K., Benston, G. J., Carmichael, D. R., Christensen, T. E., Colson, R. H., Moehrle, S. R., Rajgopal, S., Stober, T. L., Sunder, S., \& Watts, R. L. (2008). A Perspective on the SEC's Proposal to Accept Financial Statement Prepared in Accordance with International Financial Reporting Standards (IFRS) without reconciliation to US GAAP. Accounting Horizons, 22(2), 241-248. http://dx.doi.org/10.2308/acch.2008.22.2.241 
Jones, S., \& Finley, A. (2011). Have IFRS made a difference to intra-country financial reporting diversity? The British Accounting Review, 43(1), 22-38. http://dx.doi.org/10.1016/j.bar.2010.10.004

Joos, P. P. M., \& Leung, E. (2013). Investor Perceptions of Potential IFRS Adoption in the United States. The Accounting Review, 88(2), 577-609. http://dx.doi.org/10.2308/accr-50338

Kikuya, M. (2001). International harmonization of Japanese accounting standards. Accounting, Business \& Financial History, 11(3), 349-368. http://dx.doi.org/10.1080/713757317

Krisement, V. (1997). An approach for measuring the degree of comparability of financial accounting information. European Accounting Review, 6(3), 465-485. http://dx.doi.org/10.1080/096381897336674

Kvaal, E., \& Nobes, C. (2010). International differences in IFRS policy choice: A research note. Accounting and Business Research, 40(2), 173-187. http://dx.doi.org/10.1080/00014788.2010.9663390

Kvaal, E., \& Nobes, C. (2012). IFRS Policy Changes and the Continuation of National Patterns of IFRS practice. European Accounting Review, 21(2), 343-371. http://dx.doi.org/10.1080/09638180.2011.611236

Lainez, J. A., Callao, S., \& Jarne, J. I. (1996). International harmonization of reporting required by stock markets. The International Journal of Accounting, 31(4), 405-418. http://dx.doi.org/10.1016/S0020-7063(96)90029-1

Larson, R. K., \& Street, D. L. (2004). Convergence with IFRS in an expanding Europe: Progress and obstacles identified by large accounting firms' survey. Journal of International Accounting, Auditing and Taxation, 13(2), 89-119. http://dx.doi.org/10.1016/j.intaccaudtax.2004.09.002

Leuz, C. (2003). IAS Versus U.S. GAAP: Information Asymmetry-Based Evidence from Germany New Market. Journal of Accounting Research, 41(3), 445-472. http://dx.doi.org/10.1111/j.1475-679X.2003.00111.x

Leuz, C. (2010). Different approaches to corporate reporting regulation: How jurisdiction differ and why? Accounting and Business Research, 40(3), 229-256. http://dx.doi.org/10.1080/00014788.2010.9663398

Liu, Q., \& Hiltebeitel, K. (2010, November 30). IFRS Adoption in the U.S.: Why the Postponement? The CPA Journal, 26-30.

Mc Gregor, W. (1999). An Insider's View of the Current State and Future Direction of International Accounting Standard Setting. Accounting Horizons, 13(2), 159-168. http://dx.doi.org/10.2308/acch.1999.13.2.159

Meek, G. K. (1991). Capital market reactions to accounting earnings announcements in an international context. Journal of International Financial Management and Accounting, 3, 93-109. http://dx.doi.org/10.1111/j.1467-646X.1991.tb00099.x

Meek, G. K., \& Saudagaran, S. M. (1990). A survey of research on financial reporting in a transnational context. Journal of Accounting Literature, 9, 156.

Meek, G., Roberts, C., \& Gray, S. (1995). Factors influencing voluntary annual report disclosures by US, UK and continental European multinational corporations. Journal of International Business Studies, 26(3), 555-572. http://dx.doi.org/10.1057/palgrave.jibs.8490186

Murphy, M. L. (2014). The IASB's achievements in 2013: IASB Chair Hans Hoogervorst talks about IFRS in the United States and around the world. The CPA Journal, 10-11.

Nobes, C. (1993). The True and Fair View requirement: Impact on and of the Fourth Directive. Accounting and Business Research, 24(93), 35-48. http://dx.doi.org/10.1080/00014788.1993.9729462

Nobes, C. (1998). The future shape of harmonization: Some responses. European Accounting Review, 7(2), 323-330. http://dx.doi.org/10.1080/096381898336510

Nobes, C. (2004). On accounting classification and the international harmonization debate. Accounting, Organizations and Society, 29(2), 189-200. http://dx.doi.org/10.1016/S0361-3682(03)00045-X

Nobes, C. (2006). The survival of international differences under IFRS: Towards a research agenda. Accounting and Business Research, 36(3), 233-245. http://dx.doi.org/10.1080/00014788.2006.9730023

Nobes, C. (2011). IFRS Practices and the Persistence of Accounting System Classification. ABACUS, 47(3), 267-283. http://dx.doi.org/10.1111/j.1467-6281.2011.00341.x

Nobes, C., \& Parker, R. (2012). Comparative International Accounting. Pearson Education: Edimburgh.

Nobes, C., \& Stadler, C. (2013). How arbitrary are international accounting classifications? Lessons from centuries of classifying in many disciplines, and experiments with IFRS data. Accounting, Organizations 
and Society, 38(8), 573-595. http://dx.doi.org/10.1016/j.aos.2013.10.001

Ohlson, J. A., Penman, S., Bloomfield, R., Christensen, T. E., Colson, R., Jamal, K., Moehrle, S., Previts, G., Stober, T., Sunder, S., \& Watts, R. L. (2010). A Framework for Financial Reporting Standards: Issues and a Suggested Model. Accounting Horizons, 24(3), 471-485. http://dx.doi.org/10.2308/acch.2010.24.3.471

Ohlson, J. A., Penman, S., Stober, T., Sunder, S., \& Watts, R. (2010). A Research-Based Perspective on the SEC's Proposed Rule-Roadmap for the Potential Use of Financial Statements Prepared in Accordance with International Financial Reporting Standards (IFRS) by U.S. Issuers. Accounting Horizons, 24(1), 139-147. http://dx.doi.org/10.2308/acch.2010.24.1.139

Organization for Economic Co-Operation and Development. (2002). Gross Domestic Product. Retrieved from http://stats.oecd.org/Index.aspx?DataSetCode=SNA_TABLE1

Peng, S., Tondkar, R. H., Smith, J., \& Harless, D. (2008). Does Convergence of Accounting Standards Lead to the Convergence of Accounting Practices?: A Study from China. The International Journal of Accounting, 43(4), 448-468. http://dx.doi.org/10.1016/j.intacc.2008.09.009

Phillips, T. J., Drake, A., \& Luehlfing, M. S. (2010). Transparency in financial reporting: A look at rules-based versus principles-based standards. Academy of Accounting and Financial Studies Journal, 14(4), 11-28.

Pope, P. F., \& Rees, W. P. (1992). International differences in GAAP and the pricing of earnings. Journal of International Financial Management and Accounting, 4(3), 190-218. http://dx.doi.org/10.1111/j.1467-646X.1992.tb00029.x

Pownall, G., \& Schipper, K. (1999). Implications of Accounting Research for the SEC's Consideration of International Accounting Standards for U.S. Securities Offering. Accounting Horizons 13(3), 259-280. http://dx.doi.org/10.1111/j.1467-646X.1992.tb00029.x

Prather-Kinsey, J., \& Shelton, W. S. (2005). IAS versus U.S. GAAP: Assessing the quality of financial reporting in South Africa, the United Kingdom, and the United States. Advances in International Accounting, 18, 153-168. http://dx.doi.org/10.1016/S0897-3660(05)18008-8

Price Waterhouse Coopers. (2010). Similarities and Differences. A comparison of IFRS and US GAAP. PWC, London. Retrieved from http://www.pwc.com

Rahaman, A., Yammeesri, J., \& Perera, H. (2010). Financial reporting quality in international setting: A comparative study of the USA, Japan, Thailand, France and Germany. The International Journal of Accounting, 45(1), 1-34. http://dx.doi.org/10.1016/j.intacc.2010.01.001

Rahman, A. R., Perera, H. B., \& Tower, G. (1994). Accounting harmonization between Australia and New Zealand: towards a regulatory union. The International Journal of Accounting, 29(3), 316-333.

Raty, P. (1992). Reforming Finnish accounting legislation. The European Accounting Review, 413-420. http://dx.doi.org/10.1080/09638189200000031

Rees, L., \& Elgers, P. (1997). The market's valuation of non-reported accounting measures: Retrospective reconciliations of non-US and US-GAAP. Journal of Accounting Research, 35(1), 115-127. http://dx.doi.org/10.2307/2491470

Roberts, C. B., Salter, S. B., \& Kantor, J. (1996). The IASC comparability project and current financial reporting reality: An empirical study of reporting in Europe. British Accounting Review, 28, 1-22. http://dx.doi.org/10.1006/bare.1996.0001

Saudagaran, S. M., \& Meek, G. K. (1997). A review of research on the relationship between international capital markets and financial reporting by multinational firms. Journal of Accounting Literature, 16, 127-159.

Saudagaran, S., \& Biddle, G. (1995). Foreign Listing Location: A Study of MNCs and Stock Exchanges in Eight

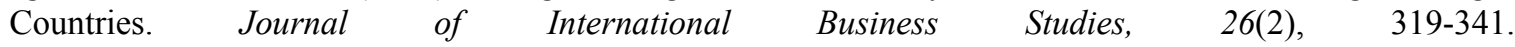
http://dx.doi.org/10.1057/palgrave.jibs.8490176

Schipper, K. (2000). Accounting research and the potential use of International Accounting Standards for cross-border securities listings. British Accounting Review, 32, 243-256. http://dx.doi.org/10.1006/bare.2000.0137

Schipper, K. (2003). Principles-Based Accounting Standards. Accounting Horizons, 17(1), 51-58. http://dx.doi.org/10.2308/acch.2003.17.1.61

Schipper, K. (2005). The introduction of International Accounting Standards in Europe: Implications for 
International Convergence. European Accounting Review, 14(1), 126. http://dx.doi.org/10.1080/0963818042000338013

Schweikart, J. A., Gray, S. J., \& Salter, S. B. (1996). An interview with Sir Bryan Carsberg, Secretary-General of the International Accounting Standards Committee. Accounting Horizons, 10(1), 110-117.

SEC (2008), Acceptance from Foreign Private Issuers of Financial Statements Prepared in Accordance with International Financial Reporting Standards without Reconciliation to US GAAP, RIN 3235-AJ90. Washington, DC: Securities and Exchange Commission. Retrieved from https://www.sec.gov/rules/final/2008/33-8879fr.pdf

Soderstrom, N. S., \& Sun, K. J. (2007). IFRS Adoption and Accounting Quality: A Review. European Accounting Review, 16(4), 675-702. http://dx.doi.org/10.1080/09638180701706732

Staunton, J. J. (2008). Multiple Dimensions of Accounting in the Development of GAAP. Abacus, 44(1), 109-135. http://dx.doi.org/10.1111/j.1467-6281.2007.00251.x

Street, D. L., \& Bryant, S. (2000). Disclosure level and compliance with IASs: A comparison of companies with and without US listings and filings. The International Journal of Accounting, 35(3), 305-329. http://dx.doi.org/10.1016/S0020-7063(00)00060-1

Street, D. L., \& Gray, S. J. (1999). How wide is the gap between IASC and US GAAP? Impact of the IASC comparability project and recent international developments. The Journal of International Accounting, Auditing and Taxation, 8(1), 133-164. http://dx.doi.org/10.1016/S1061-9518(99)00007-5

Street, D. L., \& Linthicum, C. L. (2007). IFRS in the U.S.: It May Come Sooner Than You Think: A Commentary. Journal of International Accounting Research, 6(1), 6-17. http://dx.doi.org/10.2308/jiar.2007.6.1.ix

Street, D. L., \& Shaughnessy, K. A. (1998). The quest for international accounting harmonization: A review of the standard setting agendas of the IASC, US, UK, Canada, and Australia, 1973-1997. The International Journal of Accounting, 33(2), 179-209. http://dx.doi.org/10.1016/S0020-7063(98)90026-7

Street, D. L., Nichols, N. B., \& Gray, S. (2000). Assessing the Acceptability of International Accounting Standards in the US: An Empirical Study of the Materiality of US GAAP Reconciliations by Non-US Companies Complying with IASC Standards. The International Journal of Accounting, 35(1), 27-63. http://dx.doi.org/10.1016/S0020-7063(99)00047-3

Sunder, S. (2009). IFRS and the Accounting Consensus. Accounting Horizons, 23(1), 101-111. http://dx.doi.org/10.2308/acch.2009.23.1.101

Sutton, M. H. (1997). Financial reporting in US capital markets: International dimensions. Accounting Horizons, 11(2), 96-102.

Taplin, R. (2003). Harmony, Statistical Inference with the Herfindahl H Index and C Index. Abacus, 39(1), 82-94. http://dx.doi.org/10.1111/1467-6281.00121

Taplin, R. (2004). A unified approach to the measurement of international accounting harmony. Accounting and Business Research, 34(1), 57-73. http://dx.doi.org/10.1080/00014788.2004.9729951

Taplin, R. (2010). Statistical inference using the T index to quantify the level of comparability between accounts. Accounting and Business Research, 40(1), 75-104. http://dx.doi.org/10.1080/00014788.2010.9663385

Taplin, R. (2011). The Measurement of Comparability in Accounting Research. Abacus, 47(3), 383-409. http://dx.doi.org/10.1111/j.1467-6281.2011.00345.x

Taplin, R. (2013). Measuring the comparability of company accounts conditionally. http://dx.doi.org/10.2139/ssrn.2210722

Taplin, R., Tower, G., \& Hancock, P. (2002). Disclosure (discernibility) and compliance with international accounting policies: Asia-Pacific evidence. Accounting Forum, 23(3), 293-305. http://dx.doi.org/10.1111/1467-6303.00085

Tarca, A. (2004). International Convergence of Accounting Practices: Choosing between IAS and Us GAAP. Journal of International Financial Management and Accounting, 15(1), 60-90. http://dx.doi.org/10.1111/j.1467-646X.2004.00102.x

Tarca, A. (2005). International Convergence of Accounting Standards: An investigation of the use of IAS “options" not acceptable under US GAAP. International Journal of Business Studies, 13(1), 67-86. 
Tay, J., \& Parker, R. (1990). Measuring international harmonization and standardization. ABACUS, 26(1), 71-88. http://dx.doi.org/10.1111/j.1467-6281.1990.tb00233.x

Tysiac, K. (2012). Still in flux: Future of IFRS in U.S. remains unclear after SEC report. Journal of Accountancy, September, 1-5.

Upton, W. (2010, April 16). Adopt, adapt, converge? Retrieved from http://www.ifrs.org/news/features/Pages/adopt-adapt-converge.aspx

Van Der Tas, L. G. (1988). Measuring harmonization of financial reporting practice. Accounting and Business Research, 18(70), 157-169. http://dx.doi.org/10.1080/00014788.1988.9729361

Wagenhofer, A. (2009). Global accounting standards: reality and ambitious. Accounting Research Journal, 22(1), 68-80. http://dx.doi.org/10.1108/10309610910975333

Walker, M. (2010). Accounting for varieties of capitalism: The case against a single set of global accounting standards. The British Accounting Review, 42(3), 137-152. http://dx.doi.org/10.1016/j.bar.2010.04.003

Wallace, M. (2009). Is Fair-Value Accounting Responsible for the Financial Crisis? Bank, Accounting \& Finance, $9-18$.

Weetman, P., Jones, A. E., Adams, C. A., \& Gray, S. J. (1998). Profit measurement and UK accounting standards: A case of increasing disharmony in relation to US GAAP and IAS. Accounting and Business Research, 28(3), 189-208. http://dx.doi.org/10.1080/00014788.1998.9728909

Whitehouse, T. (2013). FASB Charting New Course as Plan for Convergence Wanes. Compliance Week, 6.

World Bank Group. (2007). World Development Indicators Database, World Bank. Retrieved from http://www.scribd.com/doc/16386220/World-Bank-World-GDP-2009-PPP

Wright, A. M., Botosan, C. A., \& Colson, R. (2008). Response to the Congress Report of the SEC Advisory Committee on Improvements to Financial Reporting. Accounting Horizons, 22(4), 471-494. http://dx.doi.org/10.2308/acch.2008.22.4.471

Wright, C., \& Hobbs, S. (2010). Impact and implications of IFRS Conversion or Convergence. Bank, Accounting \& Finance, 23(4), 17-24.

Wu, C., \& Kwok, C. C. Y. (2002). Why Do US Firms Choose Global Equity Offerings. Financial Management, 31(2), 47-65. http://dx.doi.org/10.2307/3666222

Wyatt, A. (1989). Commentary on International Accounting Standards: A new perspective. Accounting Horizons, 3(3), 105-108.

Xiao, J. Z., Weetman, P., \& Sun, M. (2004). Political Influence and Coexistence of a Uniform Accounting System and Accounting Standards: Recent Developments in China. Abacus, 40(2), 193-218. http://dx.doi.org/10.1111/j.1467-6281.2004.00151.x

Yang, D. C., \& Lee, C. M. (1994). An empirical analysis of Pan-Pacific accounting practices in the 1970s. Advances in International Accounting, 6, 133-145.

Zambon, S. (1996). Accounting and business economics traditions: A missing European connection? European Accounting Review, 5(3), 401-411. http://dx.doi.org/10.1080/09638189600000026

Zambon, S., \& Crosara, V. (2007). Regulatory Changes in Accounting for Goodwill and Intangible Assets: A Study of Their First Impact on European Companies Listed on US Markets. In S. Zambon \& G. Marzo (Eds.), Visualising Intangibles: Measuring and Reporting in the Knowledge Economy (pp. 9-30). Ashgate: Aldershot.

\section{Notes}

Note 1. Publicly listed EU companies are required to adopt IAS/IFRS from fiscal year 2005.

Note 2. The term 'cosmetic' is used by Kvaal and Nobes for three issues concerning the presentation of balance sheet and Statement of Changes in Equity. For more details see Kvaal and Nobes (2010) pp. 177-178.

Note 3. With respect to equities, those classified as held for trading constitute an exception. They are recognized at market fair value, while changes in market fair value are recognized after making a choice that cannot be changed once it has been made: 1) all changes are included in the income statement (using the fair value through profit and loss method, which is mandatorily applied to all held for trading financial assets); 2) changes, i.e., 
unrealized gains and losses, are recognized net of the tax effects, in net equity and taken to profit or loss when the corresponding assets are sold or impaired or when the receivable is collected. In the event of the latter, the impairment may be taken to profit or loss immediately, if it is considered of a long-term nature, without being taken to net equity and later eliminated and recognized in the income statement. US GAAPs provide a substantially similar definition, except for the fact that the category excludes unlisted equities. Changes in market fair value are taken to the statement of comprehensive income and the potential difference relates to the recognition of the loss that could be provided for.

\section{Copyrights}

Copyright for this article is retained by the author(s), with first publication rights granted to the journal.

This is an open-access article distributed under the terms and conditions of the Creative Commons Attribution license (http://creativecommons.org/licenses/by/4.0/). 